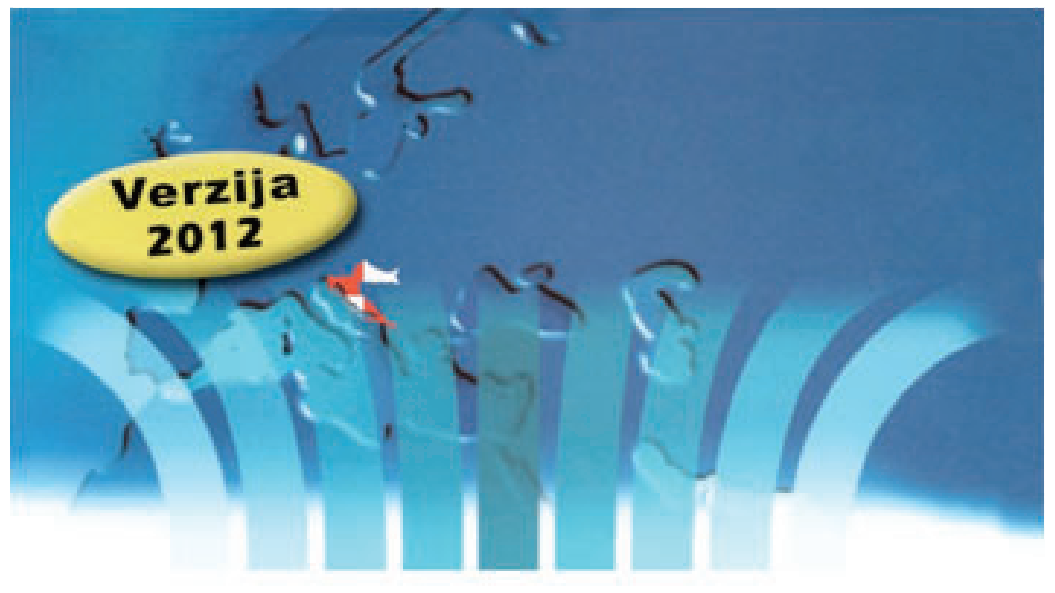

\title{
Obnovljeno 2012
}

Radna skupina za bolesti srčanih zalistaka Hrvatskoga kardiološkog društva

Predsjednik Prof.dr.sc. Jure Mirat

Radna skupina za ehokardiografiju i slikovne metode u kardiologiji Hrvatskoga kardiološkog društva

$$
\text { Predsjednik }
$$

Prof.dr.sc. Jadranka Šeparović Hanževački

\section{ESC DZEPNESMUERNICE}

\section{Preveli i uredili}

Prof.dr.sc. Jure Mirat

Prof.dr.sc. Jadranka Šeparović Hanževaćki

Doc.dr.sc. Edvard Galić

Dr.Vlatka Rešković Lukšic

\section{SMJERNICE ZA LIJEČENJE} BOLESTI SRČANIH ZALISTAKA 
Obnovljeno 2012

Radna skupina za bolesti srčanih zalistaka Hrvatskoga kardiološkog društva

Predsjednik

Prof.dr.sc. Jure Mirat

Radna skupina za ehokardiografiju i slikovne metode u kardiologiji Hrvatskoga kardiološkog društva

\section{Predsjednik}

Prof.dr.sc. Jadranka Šeparović Hanževački

\section{Preveli i uredili}

Prof.dr.sc. Jure Mirat

Prof.dr.sc Jadranka Šeparović Hanževaćk

Doc.dr.sc. Edvard Galić

Dr.Vlatka Rešković Lukšic

\section{ESC Pocket Guidelines}

Guidelines on the Management of Valvular Heart Disease* (Version 2012)

The Joint Task Force on the Management of Valvular Heart Disease of the European Society of Cardiology (ESC) and the European Association for Cardio-Thoracic Surgery (EACTS)

\section{Chairpersons}

\section{Alec Vahanian}

Service de Cardiologie

Hopital Bichat AP-HP

46 rue Henri Huchard

75018 Paris, France

Tel: +33 I 40256760

Ottavio Alfieri

s.Raffaele University Hospital

20132 Milan, Italy

Tel: +390226437109

Tax: +33140256732

Fax:+39 0226437125

Email:alec.vahanian@bch.aphp.fr

\section{Authors/Task Force Members}

Felicita Andreotti (Italy), Manuel J. Antunes (Portugal), Gonzalo Barón-Esquivias (Spain), Helmut Baumgartner (Germany), Michael Andrew Borger (Germany), Volkmar Falk (Switzerland), Bernard lue Bonis (lealy), Arturo Evangelista (Spain), Luc Pierard (Belgium), Susanna Price (UK), Hans-Joachim Schäfers (Germany), Gerhard Schuler (Germany), Janina Stepinska (Poland), Karl Swedberg (Sweden), Johanna Takkenberg (The Netherlands), Ulrich Otto Von Oppell (UK), Stephan Windecker (Switzerland), Jose Luis Zamorano (Spain), Marian Zembala (Poland)

ESC entities having participated in the development of this document: Associations: European Association of Echocardiography (EAE), European Association (HFA)

Working Groups: Acute Cardiac Care, Cardiovascular Surgery, Valvular Heart Disease, Thrombosis, Grown-up Congenital Heart Disease.

Councils: Cardiology Practice, Cardiovascular Imaging.

\section{ESC Staff:}

Veronica Dean, Catherine Despres, Nathalie Cameron - Sophia Antipolis, France Special thanks to Bogdan A. Popescu for his valuable contribution.

*Adapted from the ESC/EACTS Guidelines on the management of Valvular Heart Diseases published (European Heart Journal 2012 - doi:10.1093/eurhearti/ehs 109 an 


\section{Kazalo}

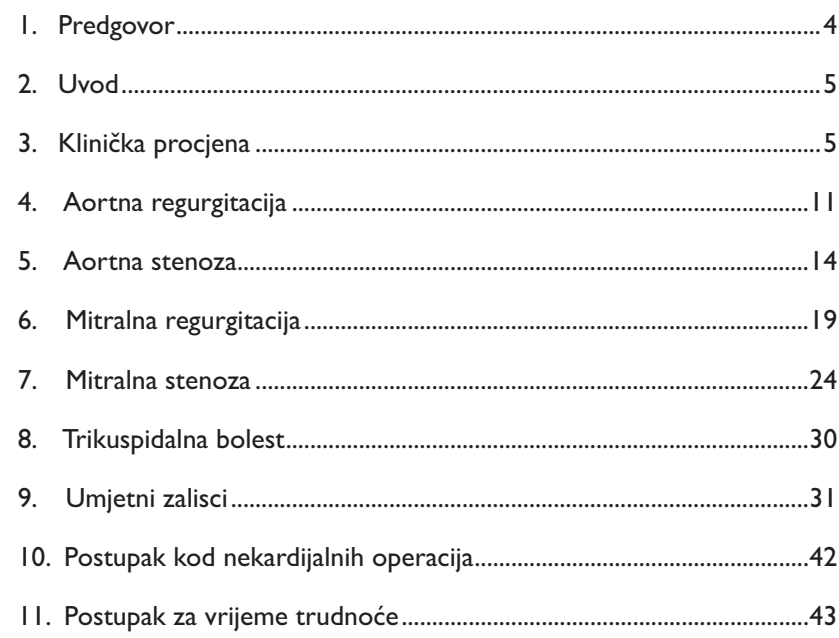

\section{Skraćenice i akronimi}

$A C E=$ angioten $i n$ konvertirajući enzim $\quad L M W H=$ niskomolekularni hepar

$A F=$ fbribcija atrij

LV = lijeva klijetka/ lijevi ventrikul LV = ijeva kijetka/ ljevi ventrikul

APTV = aktivirano parcijalno

tromboplastinsko vrijeme

$A R=$ aortna regurgitacija

$A R B=$ blokatori angiotenzinskih

receptora

$=$ aortna stenoza

ARV = zamjena aortnog zaliska

$\mathrm{BNP}=\mathrm{B}$-tip natriuretski peptid

$B S A=$ površina tijela

$C A B G=$ aortokoronarno premoštenj

$\mathrm{CAD}=$ bolest koronarnih arterija

$\mathrm{CMR}=$ magnetna rezonancija srca

CPG $=$ Odbor za primjenu smjernica

CRT $=$ resinkronizacijska terapij

$\mathrm{CT}=$ kompjutorizirana tomografija

$\mathrm{DV}=$ desna klijetka/ desni ventrikul

ECG = elektrokardiogram

$E F=$ istisna frakcija

EROA = stvarna površina

regurgitirajućeg

effective resurstate LVEF $=$ istisna frakcija lijeveklijetke
LVEDD $=$ promjer lijeve klijetke

LVEDD = promjer
na kraju dijastole

LVESD = promjer lijeve klijetke $n$

kraju sistole

$M R=$ mitralna regurgitaci

MS = mitralna stenoza

MSCT = višseslojna kompjutoriziran tomografija

NYHA = New York Heart Association PISA = izobrzinska površina sliva

(engl. proximal isovelocity surfice

area)

PMC = perkutana mitraln

komisurotomija

PVL = paravalvulanno propuštente

STS = Socity of Tho propuštanje

TAVI = posty of Thi accic Surgeors

TAve posavis

ealna hokardiografija

$T R=$ trikuspidalna regurgitacija

TS = trikuspidalna stenoza

TTE = transtorakalna ehokardiografija

$H F=$ srčano zatjenis

UFG = nefrakcionirani heparin

= srchno zajaje

NR = medunarodn

$3 \mathrm{DE}=$ trodimenzionalni ultrazvuk sr 


\section{Predgovor}

\begin{tabular}{|c|c|c|}
\hline \multicolumn{3}{|c|}{ Tablica I. Razred preporuke } \\
\hline $\begin{array}{l}\text { Razred } \\
\text { preporuke }\end{array}$ & Definicija & Preporučeni stav \\
\hline Razred I & $\begin{array}{l}\text { Dokaz i/ili opći dogovor da je } \\
\text { primijenjena terapija ili postupak } \\
\text { blagotvoran, koristan i učinkovit }\end{array}$ & Preporučen je i indiciran \\
\hline Razred II & $\begin{array}{l}\text { Postoje oprečni dokazi i/lili mišljenja } \\
\text { da je primijenjeno liječenje ili } \\
\text { postupak koristan/učinkovit }\end{array}$ & \\
\hline Razred Ila & $\begin{array}{l}\text { Većina dokaza/mišljenja ide u prilog } \\
\text { korisnostilučinkovitosti postupka }\end{array}$ & Treba ga uzeti u obzir \\
\hline Razred IIb & $\begin{array}{l}\text { Korisnost/učnkovitost postupka je } \\
\text { slabije utemeljena na dokazimal } \\
\text { mišljenjima }\end{array}$ & Može se uzeti u obzir \\
\hline Razred III & $\begin{array}{l}\text { Dokazi i opće mišljenje upućuju da } \\
\text { postupak nije koristan i učinkovit, } \\
\text { a u nekim slučajevima može biti i } \\
\text { štetan }\end{array}$ & Ne preporučuje se \\
\hline \multicolumn{3}{|c|}{ Tablica 2. Razina dokaza } \\
\hline Razina dokaza $\mathrm{A}$ & \multicolumn{2}{|c|}{$\begin{array}{l}\text { Podaci proizlaze iz više randomiziranih kliničkih } \\
\text { studija ili meta-analiza }\end{array}$} \\
\hline Razina dokaza B & \multicolumn{2}{|c|}{$\begin{array}{l}\text { Podaci proizlaze iz jedne randomizirane kliničke studije ili } \\
\text { više nerandomiziranih studija }\end{array}$} \\
\hline Razina dokaza C & \multicolumn{2}{|c|}{$\begin{array}{l}\text { Zajedničci stav stručnjaka i/lil podaci malih studija, } \\
\text { retrospektivnih studija ili registara }\end{array}$} \\
\hline
\end{tabular}

4

\section{Uvod}

Bolest srčanih zalistaka (VHD) je česta i nerijetko zahtijeva intervenciju. Budući da su dominantni uzrok bolesti zalistaka degenerativne promjene, dvije najčešće bolesti zalistaka danas su kalcificirana aortna stenoza (AS) i mitralna regurgitacija (MR), dok su aortna regurgitacija (AR) i mitralna stenoza (MS) postale rjeđe. Starija dob pacijenata s bolesti srčanih zalistaka povezana je s većom učestaloš́́ pridruženih bolesti, što povećva operativni rizik i otežav doñ̌nie odluke prid džn pali boluke za intervencijske zahvate. Drugi važan aspekt surremene bolesti srčanih zalistaka je rastući broj prethodno operiranih pacijenata koji se javljaju sa novim poteškoćama.

Ove smjernice se odnose na VHD odraslih i adolescenata, na njihovo liječenje $i$ ne bave se endokarditisom i prirođenim bolestima zalistaka u odraslih $i$ adolescenata.

Novo izdanje ESC smjernica, nakon izdanja 2007. godine bilo je potrebno iz dva razloga:

- Prvi je razlog u novim dokazima, posebno u procjeni rizika, s obzirom na to da su se promjenile dijagnostičke metode, posebno ehokardiografija te mogućnosti liječenja zahvaljujući daljnjem razvoju kirurških te mogucnosti lijecenja zahvaljujuci daljnjem razvoju kirurških rekonstrukcijskih zahvata na zaliscima i uvođenju perkutanih intervencijskih
tehnika, posebno postavljanje aortnog zaliska putem katetera (TAVI) i perkutanih zahvata na zaliscima (edge to edge).

- Drugi razlog je važnost suradnje između kardiologa i kardiokirurga u liječenju bolesnika s bolestima srčanih zalistaka koja je dovela do izdavanja zajedničkih dokumenata ESC i EACTS.

\section{Opće upute}

\section{I. Klinička procjena}

Ciljevi u procjeni bolesnika s oboljenjima srčanih zalistaka su dijagnoza, određivanje težine greške te procjena mehanizama i posljedica. Bilo bi najbolje da odluku donosi „ekspertni tim za srce“ koji uključuje kardiologe, kardiokirurge, specijaliste za slikovne tehnike, anesteziologe i ako je potrebno obiteljske liječnike, gerijatre i specijaliste za intenzivnu skrb. Ovakav pristup $s$,timom za srce" posebno se preporučuje kod visokorizičnih bolesnika a važan je i u drugim situacijama, kao kod bolesnika koji nemaju tegoba i gdje je procjena mogućnosti popravka zaliska ključna za donošenje odluka. 


\section{Tablica 3. Osnovna pitanja u procjeni bolesnika za zahvatna srčanim} zaliscima

- Radi li se o teškoj bolesti srčanih zalistaka?

Ima li bolesnik simptome?

- Jesu li ti simptomi uzrokovani bolesnim zaliscima?

- Koliko je očekivano trajanjeai kvaliteta bolesnikova života?

- Premašuje li očekivani rizik operacije rizik spontanog ishoda bez operacije?

- Pristaje li bolesnik na zahvat?

- Kakve su lokalne mogućnosti za planiranje najboljeg zahvata?

Očekivano trajanje żvota procieniuje se prema dobi, spolu, ostalim bolestima i očekkivanom trajanju živo specifičnom za svaku zemlju.

Klinička procjena je prvi korak u dijagnostici i određivanju težine VHD.

Ultrazvuk srca ključna je tehnika koja potvrđuje dijagnozu VHD, procjenjuje njenu težinu prognozu. U procjeni težnne $V H D$ potrebno je provjeriti poklapanje razlicitith ultrazvučni mjera i izracunatih vrijednosti te ih usporediti s anatomijom i mehanizmima VHD. Treb provjeriti jesu li nalazi u skladu s klinickom procjenom.

Procjena težne stenoze srčnog zaliska trebala bi kombinirati nalaz površine zaliska s polaza



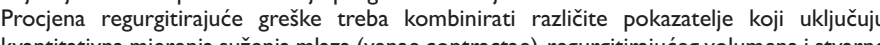
površine regurgitirajućeg ušća (EROA) koji je manje ovisan o projicajuceg volumena i stvarne mlaza obojenim Dopplerom. lpak kvantitativna prociena ima svoja ograničenja i njezina upotreba zahtijeva iskustvo i uključivanje brojnih mjerenja, a ne oslanjanje na pojedin parametar

\begin{tabular}{|c|c|c|c|}
\hline & $\begin{array}{r}\text { Aortna } \\
\text { stenoza } \\
\end{array}$ & $\begin{array}{l}\text { Mitralna } \\
\text { stenoza } \\
\end{array}$ & $\begin{array}{c}\text { Trikuspidalna } \\
\text { stenoza } \\
\end{array}$ \\
\hline Površina ušća zaliska (cm2) & $<1,0$ & $<1,0$ & - \\
\hline $\begin{array}{l}\text { Indeksirana površina ušća zaliska } \\
(\mathrm{cm} 2 / \mathrm{m} 2 \mathrm{BSA})\end{array}$ & $<0,6$ & - & - \\
\hline Srednji gradijent $(\mathrm{mmHg})$ & $>40 \mathrm{a}$ & $>10 \mathrm{~b}$ & $\geq 5$ \\
\hline Najviši gradijent $(\mathrm{m} / \mathrm{s})$ & $>4,0 \mathrm{a}$ & - & - \\
\hline Omjer brzina (velocity ratio) & $<0,25$ & - & - \\
\hline
\end{tabular}

aKod bolesnika s urednom istisnom frakcijom/transvalvularnim protokom

kladu sa srčanim ritmom Preuzeto od Baumgartner i suradnici- Echocardiographyc
for clinical practice. EurJ Echocardiography 2009; 1 : I-25.

Kod AR, MS, MR, TR transtorakalna ehokardiografija (TTE) omogućava preciznu procjenu valvularne morfologije, koja je važna u izboru kandidata za kirurški zahvat rekonstrukcije srčanih zalistaka, perkutanu mitralnu komisurotomiju (PMC) ili reparaciju edge-to-edge. Ehokardiografija treba uključivati jasnu procjenu cijelokupnog valvularnog aparata, uzlazne aorte te pokazatelja uvećanja i funkcije lijeve klijetke (LV). Dimenzije LV treba usporediti u odnosu na BSA. Na kraju se treba procijeniti plućni tlak i funkcija desne klijetke (RV).

Trodimenzionalna ehokardiografija (3DE) korisna je u procjeni anatomske slike i može utjecati na izbor zahvata, posebno mitralnog zaliska.

Transezofagealna ehokardiografija (TEE) se koristi kada je TTE slabije kvalitete ili kada se sumnja na trombozu, disfunkciju proteze ili endokarditis. Intraproceduralni TEE nam omogućava praćenje rezultata kirurškog zahvata kod rekonstrukcije zaliska ili perkutanih procedura.Visoko-kvalitetni TEE obavezan je kad se izvodi popravljanje samog zaliska.

Test opterećenja se koristi u procjeni VHD i/ili njihovih posljedica. Koristan je za otkrivanje prikrivenih simptoma u onih koji ih nemaju ili ih nisu svjesni. Ima dodatnu važnost u stratifikaciji rizika kod AS.

Stres ehokardiografija može pružiti dodatne informacije u pronalaženju kardijalnog uzroka dispneje i u određivanju prognoze MR i AS. Međutim, ova pretraga nije u širokoj upotrebi, može biti tehnički zahtjevna i traži veliko iskustvo.

Određivanje kontraktilne rezerve (engl. flow reserve or contracile reserve) pomoću stres ehokardiografije s niskim dozama dobutamina korisno je u procjeni težine operativnog rizika AS s oštećenom funkcijom LV i malim gradijentom.

Magnetska rezonancija srca (CMR) koristiti se kod bolesnika kod kojih je ehokardiografski nalaz loše kvalitete ili postoji nepodudarnost rezultata, kako bi se odredila težina regurgitirajuće lezije te volumeni i funkcija lijeve klijetke (LV). CMR je referentna metoda u procjeni volumena i funkcije desne klijetke (RV).

Višeslojna kompjutorizirana tomografija (MSCT) veoma je korisna u procjeni težine i lokacije aneurizme uzlazne aorte. Može biti korisna i u isključivanju CAD kod bolesnika s niskim rizikom za aterosklerozu. MSCT ima ključnu ulogu u određivanju visoko rizičnih bolesnika koji su kandidati za TAVI.

B-tip natriuretskog peptida (BNP) koristan je u određivanju rizika kod AS i MR.

Koronarna angiografija je neophodna za otkrivanje pridružene CAD u planiranju 
kirurškog zahvata. Može se izostaviti jedino kod bolesnika s niskim rizikom za aterosklerozu ili u rijetkim situacijama kada njezin rizik prelazi očekivanu dobit, kao na primjer kod akutne disekcije aorte, velikih aortnih vegetacija ispred koronarnih ušća ili kod okluzivne tromboze proteze koja vodi nestabilnom hemodinamskom stanju. Kateterizaciju srca treba ograničiti na slučajeve kod kojih je neinvazivna procjena nedovoljna ili se ne poklapa s kliničkim nalazom.

Profilaksu endokarditisa treba razmotriti kod svakog pacijenta s VHD i prilagoditi njegovom individualnom riziku.

\begin{tabular}{|c|c|c|c|}
\hline \multicolumn{4}{|c|}{$\begin{array}{r}\text { Tablica 5. Ehokardiografski kriteriji teške } r \\
\text { sveobuhvatni pristup }\end{array}$} \\
\hline & $\begin{array}{l}\text { Aortna } \\
\text { regurgitacija }\end{array}$ & $\begin{array}{l}\text { Mitralna } \\
\text { regurgitacija }\end{array}$ & $\begin{array}{l}\text { Trikuspidalna } \\
\text { regurgitacija }\end{array}$ \\
\hline \multicolumn{4}{|l|}{ Kvalitativni } \\
\hline Morfologija zaliska & $\begin{array}{c}\text { Patološko } \\
\text { lepršanje (flail)/ } \\
\text { velikaneprijanjajuća } \\
\text { površina }\end{array}$ & $\begin{array}{l}\text { Lepršanje listića/ruptura } \\
\text { papilarnog mišića/veliki } \\
\text { koaptacijski defekt }\end{array}$ & $\begin{array}{c}\text { Veliki } \\
\text { koaptacijski } \\
\text { defekt / } \\
\text { lepršanje/ }\end{array}$ \\
\hline $\begin{array}{l}\text { Obojeni } \\
\text { regurgitirajući } \\
\text { mlaz }\end{array}$ & $\begin{array}{l}\text { Velik u centralnom } \\
\text { mlazu, varijabilan } \\
\text { kod ekscentričnog } \\
\text { mlaza }^{\text {a }}\end{array}$ & $\begin{array}{l}\text { Jako velik središnji mlaz ili } \\
\text { ekscentrični mlaz koji se } \\
\text { približavai doseže stražnju } \\
\text { stijenku lijevog atrija }\end{array}$ & $\begin{array}{c}\text { Jako velik } \\
\text { centralni } \\
\text { mlaz ili } \\
\text { ekscentričan } \\
\text { mlaz koji } \\
\text { udara o } \\
\text { stijenku }\end{array}$ \\
\hline $\begin{array}{l}\text { CW signal } \\
\text { regurgitirajućeg } \\
\text { mlaza }\end{array}$ & Gust & Gust/triangularan & $\begin{array}{l}\text { Gust/ } \\
\text { triangularan s } \\
\text { ranim vrškom } \\
\text { (vršak }<2 \mathrm{~m} / \mathrm{s} \\
\text { kod masivne } \\
\text { TR) }\end{array}$ \\
\hline Ostali & $\begin{array}{c}\text { Holodijastolički } \\
\text { obrat u silaznoj aorti } \\
\text { (EDV >20 cm/s) }\end{array}$ & $\begin{array}{l}\text { Velika površina konvergencije } \\
\text { sliva }^{a}\end{array}$ & - \\
\hline
\end{tabular}

\begin{tabular}{|c|c|c|c|c|}
\hline \multicolumn{5}{|l|}{\begin{tabular}{|l} 
Semikvantitativni \\
\end{tabular}} \\
\hline \begin{tabular}{|l} 
Vena contracta - \\
širina u $\mathrm{mm}$
\end{tabular} & $>6$ & \multicolumn{2}{|c|}{$\geq 7{\text { (>8 za biplani })^{b}}^{b}$} & $>7^{\mathrm{a}}$ \\
\hline $\begin{array}{l}\text { Uzlazni venski } \\
\text { protok }^{c}\end{array}$ & - & \multicolumn{2}{|c|}{$\begin{array}{l}\text { Sistolički obrat protoka } \\
\text { u plućnim venama }\end{array}$} & $\begin{array}{c}\text { Obrat } \\
\text { sistoličkog } \\
\text { protoka u } \\
\text { hepatalnim } \\
\text { venama }\end{array}$ \\
\hline Utok (inflow) & - & \multicolumn{2}{|c|}{$\begin{array}{l}\text { Dominantan E-val } \\
\geq \geq 1,5 \mathrm{~m} / \mathrm{s}^{2}\end{array}$} & $\begin{array}{l}\text { Dominantan } \\
\text { E-val } \geq 1 \mathrm{~m} / \mathrm{s}^{2}\end{array}$ \\
\hline Ostali & $\begin{array}{l}\text { Poluvrijemepada } \\
\text { tlaka } \\
<200 \mathrm{~ms}^{\mathrm{f}}\end{array}$ & \multicolumn{2}{|c|}{$\begin{array}{c}\text { TVI mitralni/TVI aortni } \\
>1,4\end{array}$} & $\begin{array}{l}\text { PISA radijus } \\
>9 \mathrm{~mm}^{\mathrm{C}}\end{array}$ \\
\hline \multicolumn{5}{|l|}{ Kvantitativni } \\
\hline & & primarna & sekundarna & \\
\hline EROA $(\mathrm{mm} 2)$ & $\geq 30$ & $\geq 40$ & $\geq 20$ & $\geq 40$ \\
\hline $\begin{array}{c}\text { R Volumen (ml/ } \\
\text { otkucaj) }\end{array}$ & $\geq 60$ & $\geq 60$ & $\geq 30$ & $\geq 45$ \\
\hline $\begin{array}{c}\text { + uvećanje } \\
\text { srčanih šupljina/ } \\
\text { žila }\end{array}$ & LV & LV, LA & & $\begin{array}{c}\text { DV, DA i } \\
\text { donje šuplje } \\
\text { vene }\end{array}$ \\
\hline
\end{tabular}

$\mathrm{CW}=$ kontinuirani val; $E D V=$ brzina na kraju dijastole; $E R O=$ stvarna površina regurgitirajućeg otvora; $\mathrm{LA}$

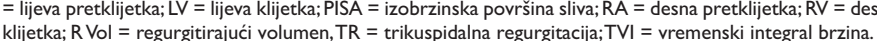
apri Nyquist granici od $50-60 \mathrm{~cm} / \mathrm{s}$.

‘Ako ne postoje drugi razlozi sistoličkog slablienja (fibrilacija atrija, povišen tlak u pretklijetkama). povećanog tlaka u lijevom atriju.

'Poluvriieme pada tlaka je skrácéno $s$ povén usem tham atriju. kod bolesnika s proširenom propuštajućom aortom ili širenjem kod kronične aortne regurgitacije. \&Bazični pomak Nimquist granice od $28 \mathrm{~cm} / \mathrm{s}$

MR $\mathrm{E}$ EROA $>20 \mathrm{~mm} 2$ i regurgitirajućim volumenom

Preuzeto od Lancellotti i sur. - preporuke za procienu valvularne regurgitacije. Prvi dio:
regurgitacija aorte i zaliska plućne arterije (nativa bolest zaliska). Eur J Echocardiography 2010; /1:307-332. 
Donošenje odluke o intervenciij i tipu intervencije kod bolesnika s VHD bazira se na individualnoj analizi rizika i koristi koja uspoređuje spontani tijek bolesti s očekivanim rezultatima intervencije, u skladu s posebnostima VHD i pridruženim bolestima. Procjena pridruženih bolesti je klinička. Kod starijih osoba dob ne treba smatrati kontraindikacijom za kirurški zahvat. Bodovanje, primjerice EuroScore ili STS uključuju više čimbenika i korisni su u procjeni operacijskog rizika, iako imaju ograničenja. Procjena rizika mora se prvenstveno zasnivati na kliničkoj procjeni „tima za srce“ uz pomoć bodovnih sustava. Pri donošenju odluke treba uzeti u obzir očekivano trajanje

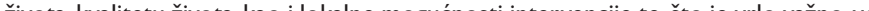

\subsection{Liječenje pridruženih stanja}

Bolest koronarnih arterija

Korištenje testa opterećenja u otkrivanju CAD kod pridružene teške VHD razočaravajuće je zbog njegove niske dijagnostičke vrijednosti i mogućih rizika.

Sažetak liječenja pridružene CAD dat je u Tablici 6.

\section{Aritmije}

Kardioverzija nije indicirana prije intervencija kod bolesnika s teškom VHD, osim u slučaju gdje AF pogoršava hemodinamsko stanje.

Oralna antikoagulacijska terapija s ciljnim vrijednostima INR između 2 do 3 preporučuje se kod bolesnika s nativnim VHD i bilo kojim tipom fibrilacije atrija. Kod MS ciljne vrijednosti INR trebaju biti u gornjim granicama.
Tablica 6.Liječenje koronarne bolesti kod bolesnika

s oštećenim srčanim zaliscima

Razred $^{a}$

Dijagnoza bolesti koronarnih arterija

Preporučuje se učiniti koronarnu angiografijuc prije

operativnog zahvata na zaliscima kod bolesnika $s$ teškom

(

- koronarna bolest u anamnezi

sistolička disfunkrija lieve klijetke

- kod muškaraca starijih od 40 godina i postmenopauzalnih

$\bullet \geq I$ kardiovaskularni rizični čimbenik

\begin{tabular}{|l|l|l|l|}
\hline Koronarna angiografija se preporučuje u sekundarnoj & I & C \\
\hline
\end{tabular}

Indikacija za revaskularizaciju miokarda

CABG se preporučuje kod pacijenata s primarnom

indikacijom za kirurški zahvat na aortnom
i sa stenozom koronarne arterije $\geq 70 \% \Theta$

CABG se treba razmotriti kod pacijenata $s$ primarnom
indikacijom za kirurški zahvat na aortnom/mitralnom zalisku

i sa stenozom koronarne arterije $50-70 \%$

\begin{tabular}{|c|c|}
\hline \multicolumn{1}{|c|}{} & \multicolumn{1}{c|}{} \\
\hline & $c$ \\
\hline 1 & \\
\hline 1 & $c$ \\
\hline I & $c$ \\
\hline IIa & $c$ \\
\hline
\end{tabular}

CABG = aortokoronarno premoštenje.

aRazred preporuke: bRazina dokaza

aRazred preporuke; bRazina dokaza

fij može se koristiti u isključivanju koronarne bolesti kod bolesnika dBol u prsima, patološki neinvazivni testovi

e $250 \%$ može se uzeti u obzir kod stenoze glavnog debla.

\section{AORTNA REGURGITACIJA}

\section{I. Indikacije za kirurški zahvat}

Kod kronične AR ciljevi operacije su izbjegavanje sistoličke disfunkcije lijeve klijetke i/ili aortnih komplikacija.

Izbor kirurskog zahvata prilagođava se iskustvu tima, prisutnoj aneurizmi korijena, posebnostima listića, očekivanom trajanju života i željenom antikoagulacijskom stanju. 


\begin{tabular}{|c|c|c|}
\hline & Razred $^{a}$ & Razina $^{b}$ \\
\hline \multicolumn{3}{|c|}{ A.Indikacije za kirurški zahvat kod teške aortne regurgitacije } \\
\hline Indiciran je kod bolesnika sa simptomima. & & $\bar{B}$ \\
\hline $\begin{array}{l}\text { Indiciran je kod bolesnika bez simptoma s LVEF } \leq 50 \% \\
\text { u } \\
\text { mirovanju }\end{array}$ & I & B \\
\hline $\begin{array}{l}\text { Indiciran je kod bolesnika koji se podvrgavaju CABG ili } \\
\text { kirurškom zahvatu na uzlaznoj aorti ili drugom zalisku. }\end{array}$ & I & c \\
\hline $\begin{array}{l}\text { Treba uzeti u obzir kod bolesnika bez simptoma s EF } \\
>50 \% \text { u } \\
\text { mirovanju, s teškom dilatacijom LV: } L \text { EVDD }>70 \mathrm{~mm} \text { ili } \\
\text { LVESD }>50 \mathrm{~mm} \text { ili LVESD }>25 \mathrm{~mm} / \mathrm{m}^{2} \text { BSAc }\end{array}$ & II & c \\
\hline \multicolumn{3}{|c|}{$\begin{array}{l}\text { B.Indikacije za kirurški zahvat kod bolesti aortnog korijena (bez obzira } \\
\text { na težinu AR) }\end{array}$} \\
\hline $\begin{array}{l}\text { Indiciran je kod bolesnika koji imaju bolest aortnog } \\
\text { korijena s najvišsim promjerom uzlazne aorted } \geq 50 \mathrm{~mm} \\
\text { kod Marfanovogsindroma. }\end{array}$ & I & C \\
\hline  & Ila & c \\
\hline
\end{tabular}

$C A B G=$ aortokoronarno premoštenje. $L V=$ lijeva klijetka; $L V E D D=$ promjer lijeve klijetke na kraju dijastole; $L V E S D=$ promjer lijeve klijetke na kraju sistole.

${ }^{2}$ Razred preporuke; bRazina dokaza

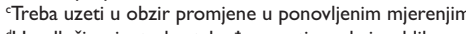

u odlucivanju treba takoder uzeti u obzir oblik različitih dijelova aorte. Niži prag treba koristiti kod aortnom zalisku. Disekclua aorte u obiteljskoj anamnezi ifili uvećanje aortnog promjera $>2 \mathrm{~mm} / g \circ d i n u$ (u ponovnim drugih tehnika), teška $A R$ ili mitralna regurgitacija, planiranje trudnoce.

12

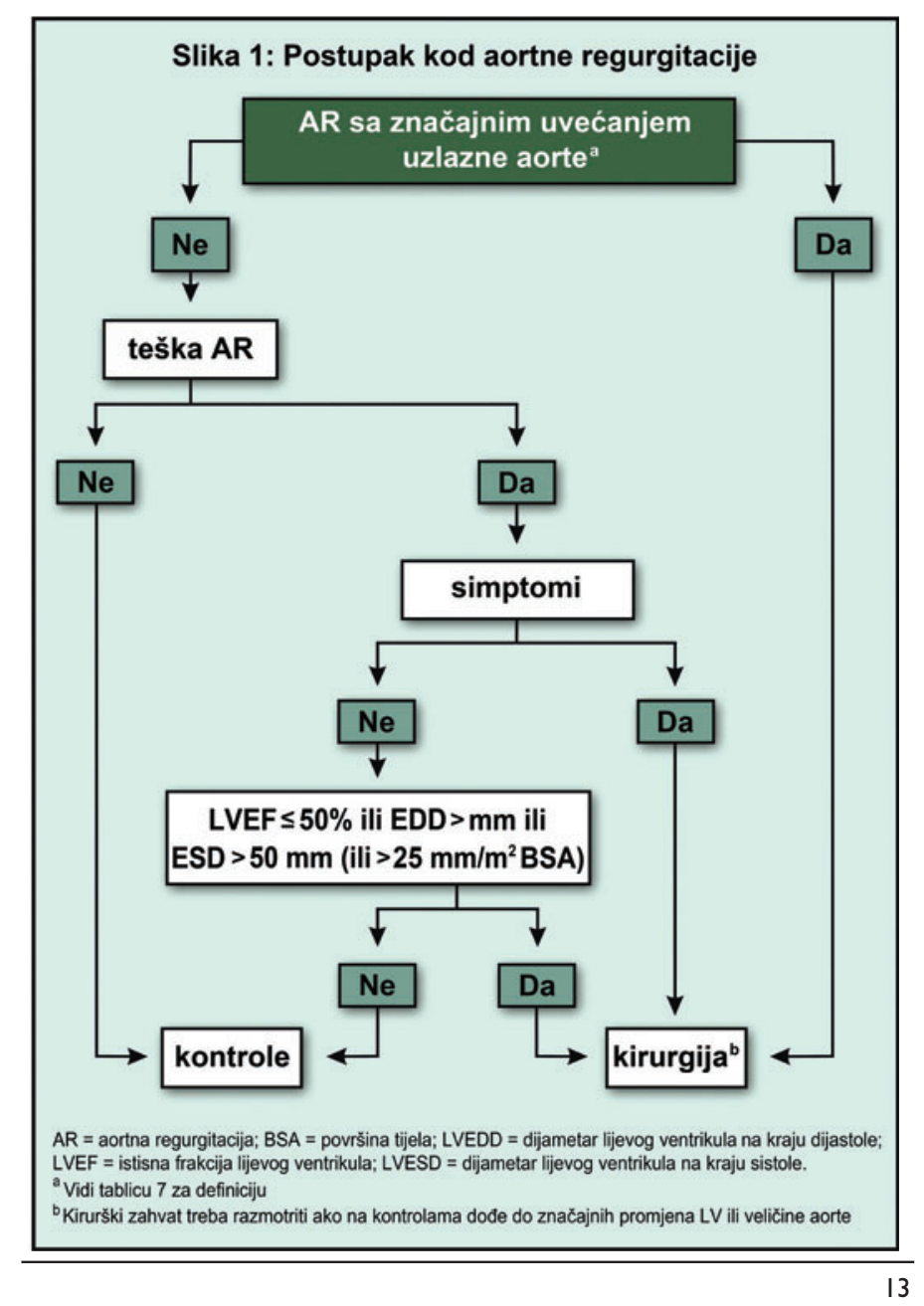


'Koarktacija aorte, arterijska hipertenzija, disekcija aorte u obiteljskoj anamnezi ili uvéanjje aortnog promjer $>2 \mathrm{~mm} / \mathrm{godinu}$ (u ponovnim mjerenjima korištenjem iste slikovne metode i usporednih mjerenjem na istoj razini aorte s potvrdom drugih tehnika

\subsection{Liječenje lijekovima}

Vazodilatatori i inotropna sredstva mogu se koristiti u kratkoročnoj terapiji u svrhu poboljšanja bolesnikovog stanja kod teškog srčanog popuštanja (HF) prije pristupanja kirurškom zahvatu na aortnom zalisku. Ne postoje dokazi o korisnosti vazodilatatora kod bolesnika bez simptoma koji nemaju arterijsku hipertenziju.

\subsection{Kontrole}

Svi bolesnici $s$ teškom AR i normalnom funkcijom LV trebaju doći na kontrolni pregled za 6 mjeseci, nakon prvog pregleda. Bolesnici sa stabilnim parametrima trebaju dolaziti na kontrolni pregled jednom godišnje. Bolesnicima s proširenom aortom i posebno onima s Marfanovim sindromom ili dvolisnim aortnim zaliskom treba učiniti ehokardiografiju jednom godišnje.

\section{AORTNA STENOZA}

Stav u liječenju inoperabilnih $\mathrm{i}$ visokorizičnih bolesnika za kirurški zahvat promijenio se uvođenjem TAVI-ja.

\section{I. Indikacije za kirurški zahvat}

Rana zamjena zaliska posebno se preporučuje kod bolesnika s teškom AS koji imaju simptome i koji su kandidati za kirurški zahvat. Ukoliko je srednji gradijent $>40 \mathrm{mmHg}$, praktično ne postoji donja granica EF za operaciju.

Liječenje bolesnika $s$ klasičnim oblikom AS s malim protokom, malim gradijentom (površina zaliska $<1,0 \mathrm{~cm} 2, E F<40 \%$, srednji gradijent $<40 \mathrm{mmHg}$ ) znatno je teže. U konačnoj odluci treba uzeti u obzir kliničko stanje bolesnika (posebno prisutnost i težinu pridruženih bolesti), stupanj kalcifikacije zaliska, težinu koronarne bolesti i pouzdanost revaskularizacije.

Novi fenomen je paradoksna AS s malim protokom, malim gradijentom is normalnom EF, koja zahtijeva posebnu pozornost s obzirom na to da postoji ograničeno iskustvo njezinog prirodnog tijeka i rezultata kirurških zahvata. U ovakvim slučajevima kirurški zahvat treba učiniti samo ako bolesnik ima simptome a razumna procjena upućuje na značajno suženje zaliska.

Liječenje teške AS kod bolesnika koji nemaju simptome je proturječno. Rani elektivni kirurški zahvat treba učiniti u probranih bolesnika s niskim operacijskim rizikom.

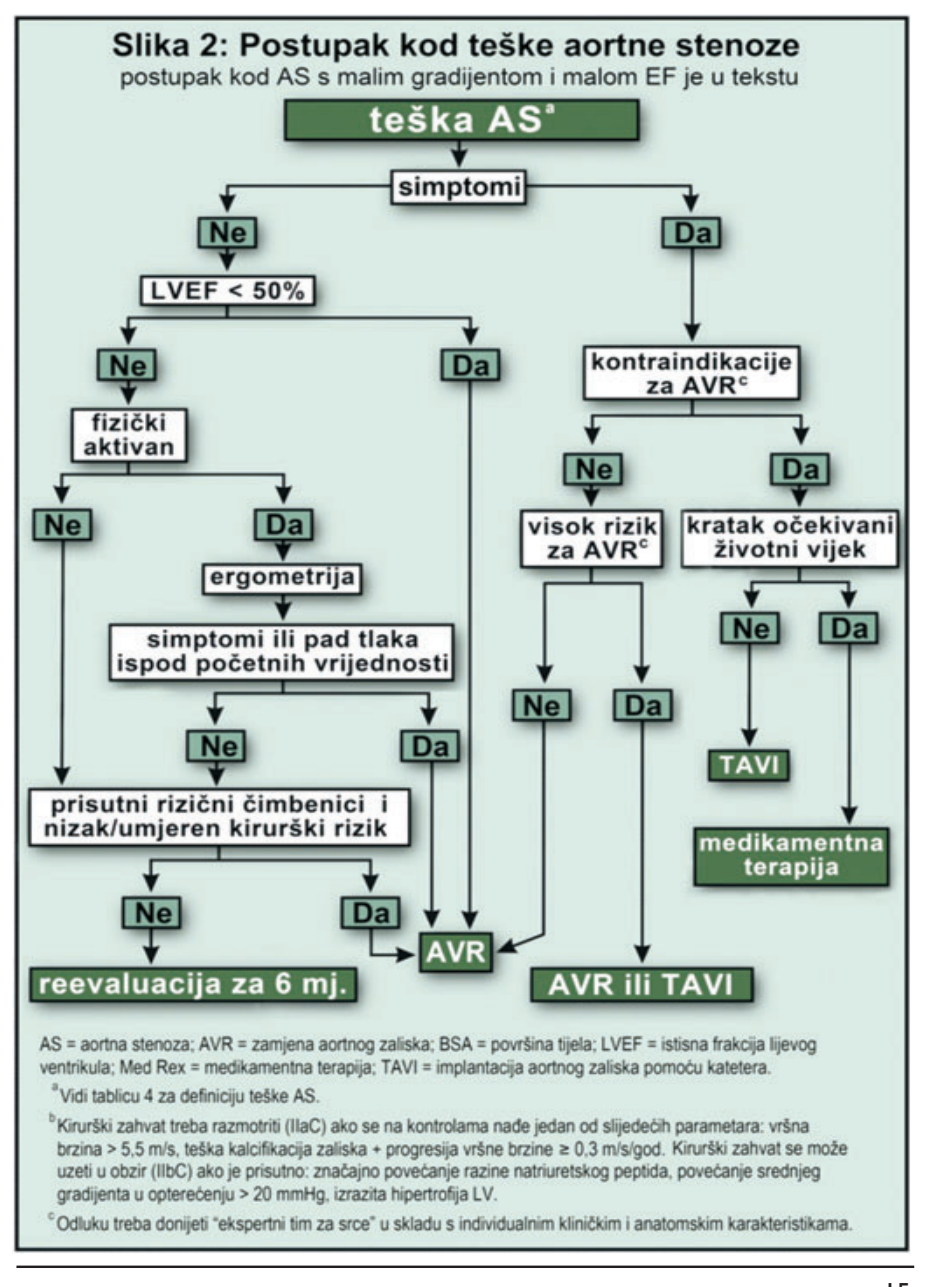


Tablica 8. Indikacije za zamjenu aortnog zaliska (AVR) kod aortne stenoze

Indicirana je kod bolesnika s teškom AS i bilo kojim simptomom koji je s njom povezan.

Indicirana je kod bolesnika s teškom AS koji se podvrgava CABG, kirurškom zahvatu na uzlaznoj aorti ili nekom drugom zalisk

Indicirana je kod bolesnika bez simptoma $s$ teškom AS sistoličkom disfunkcijom LV (LVEF <50\%) koja nema drug uzrok

Indicirana je kod bolesnika bez simptoma s teškom AS patološkim testom opterećenja koji otkriva simptome naporu koji su jasno povezani s AS.

Treba uzeti u obzir kod visoko rizičnih bolesnika s teškim simptomima AS koji su pogodni za TAVl, ali kod koijh tim za srce dao prednost kirurgiji zbog boljih očekivanih rezultata, na osnovi individualnog profila rizika i anatomske pogodnosti.

Treba uzeti u obzir kod bolesnika bez simptoma s teškom pada krvnog tlaka ispod početnih vrijednosti.

Treba uzeti u obzir kod bolesnika s umjerenom $\mathrm{AS}^{\mathrm{c}}$ koji se podvrgavaju CABG, kirurškom zahvatu na uzlaznoj aorti nekom drugom zalisku.

Treba uzeti u obzir kod bolesnika sa simptomima sniskim protokom, niskim gradijentom $(<40 \mathrm{mmHg}$ ) kod AS normalnom EF samo nakon pažljive procjene teške AS.

Treba uzeti u obzir kod bolesnika sa simptomima kod teške AS s niskim protokom, niskim gradijentom i sniženom te dokazanom kontraktilnom rezervom.
Razred $^{\mathbf{a}}$ Razina $^{\mathrm{b}}$

Treba uzeti u obzir kod bolesnika bez simptoma s normalnom EF i nijednom od navedenih promjena $u$ opterecenja, ako je kirurški rizik nizak i ako imamo: -Veoma tešku AS definiranu najvišom transvalvularnom brzinom $>5,5 \mathrm{~m} / \mathrm{s}$ ili

i progresiju transvalvularne $0,3 \mathrm{~m} / \mathrm{s}$ na godinu.

Treba uzeti u obzir kod bolesnika sa simptomima i teškom AS $s$ niskim protokom i niskim gradijentom $s$ disfunkcijom LV bez kontraktilne rezerve.

Može se uzeti u obzir kod bolesnika bez simptoma s teškom AS i normalnom EF bez i jedne gor spomenute promjeneu testu opteréc i ja ako je nizak iprisuta jedna od sljedecih ok jo nizi: -Značajno povišena razina natriuretskog peptida ponovljenim mjerenjima bez drugog obrazloženja.

- Povišensrednji gradijent tlaka u opterećenju za $>20$ $\mathrm{mmHg}$.

-Izrazita hipertrofija LV u odsutnosti hipertenzije.

$A S=$ aortna stenoza; $A V R=$ zamjena aortnog zaliska; $B S A=$ pouršina tijela; $C A B G=$ aortokoronarno AS = a 'Razred preporuke; bRazina doka

Umjerena AS je definirana porršinom zaliska $1,0-1,5 \mathrm{~cm} 2(0,6-0,9 \mathrm{~cm} 2 / \mathrm{m} 2 \mathrm{BSA})$ ili srednjim aortnim gradijentom $25-40 \mathrm{mmHg}$ kod normalnog protoka. Ipak je potrebna klinička procjena.


AS) mora biti pažljivo isključeno. Pogledaj puni tekst (procjena AS).

\subsection{Indikacije za balonsku valvuloplastiku}

Balonska valvuloplastika se može uzeti u obzir kao most do kirurškog zahvata ili TAVI-ja kod bolesnika koji su hemodinamski nestabilni i s visokim rizikom za kirurški zahvat ili kod bolesnika s teškom AS i simptomima koji trebaju biti podvrgnuti velikom nekardiološkom kirurškom zahvatu. 


\subsection{Indikacije za postavljanje aortnog zaliska putem}

katetera -TAVI

TAVI treba izvoditi u bolnicama koji imaju kardiokirurgiju. "Tim stručnjaka za srce" procjenjuje individualni rizik bolesnika kao i tehničku pogodnost je li TAVI najbolji izbor za ovakve bolesnike.

Kontraindikacije, bilo kliničke ili anatomske, trebaju se prepoznati. Bolesnici pogodni za ovaj zahvat imaju očekivano trajanje života duže od jedne godine i očekivano poboljšanje kvalitete života. Na osnovi postojećih spoznaja i odluke stručnog tima za srce TAVI se preporučuje kod bolesnika $s$ teškom AS koji imaju simptome i za koje se smatra da nisu pogodni za klasičan kirurški zahvat. TAVI treba uzeti u obzir kod probranih bolesnika s visokim rizikom koji su kandidati za kirurški zahvat, razmotrivši prednosti i nedostatke obiju tehnik.

\subsection{Liječenje lijekovima}

Statinska terapija se ne treba koristiti kod AS kako bi usporila njezinu progresiju. S druge strane, strogo se preporučuje liječenje čimbenika rizika za aterosklerozu.

\subsection{Kontrole}

Pacijent koji nema tegobe pažljivo se educira o važnosti kontrola i prijavljivanju simptoma čim se oni pojave. Takav se bolesnik treba kontrolirati svakih 6 mjeseci i reevaluirati postoje li simptomi ili je došlo do smanjene tolerancije na napor. Od koristi je i određivanje natriuretskog peptida.

Kada su prisutne značajne kalcifikacije kod blage i umjerene AS bolesnik se treba kontrolirati jednom godišnje. Mlađi bolesnici s AS bez značajnih kalcifikacija mogu se kontrolirati i u dužim vremenskim intervalima od 2 do 3 godine.

Za sada TAVI se nebi trebao provoditi kod bolesnika s umjerenim rizikom za kirurški zahvat. 
Tablica I0. Preporuke za postavljanje aortnog zaliska putem katetera (TAVI)

\section{Preporuke}

\begin{tabular}{|l|l|} 
Razred $^{\mathbf{a}}$ & Razina \\
\hline
\end{tabular}

TAVI-ju bi se trebalo pristupiti ukoliko postoji multidisciplinarni „tim za srce“ koji uključuje kardiologa, kardiokirurga a po potrebi i druge specijaliste.

TAVI bi se trebao provoditi samo u bolnicama kojima postoji kardiokirurgija.

TAVI je indiciran kod bolesnika s teškom simptomatskom AS koji nisu pogodni za AVR prema procjeni ,tima za srce“" i kod kojih se očekuje poboljšanje kvalitete života i trajanje života duže od jedne godine uzevši u obzir i ostale bolesti.

TAVI treba uzeti u obzir kod visoko rizičnih bolesnika $s$ teškom simptomatskom AS koji su pogodni za kirurški zahvat, ali „tim za srce“ daje prednost TAVI-ju zbog individualnog profila rizika i anatomske pogodnosti.

\begin{tabular}{|c|c|}
\hline I & C \\
\hline I & C \\
\hline I & B \\
\hline IIa & B \\
\hline
\end{tabular}

AS = aortna stenoza; $\quad$ AVR $=$ zamjena aortnog zaliska; $\quad$ TAVI = implantacija aortnog zaliska preko katetera.

aRazred proporuke: bRazina de

\section{MITRALNA REGURGITACIJA}

Ovdje se odvojeno obrađuju primarna i sekundarna MR u skladu s njihovim mehanizmima.

\section{I. Primarna MR}

Primarna MR uključuje sve etiologije s oštećenjem koje pogađa jedan ili nekoliko dijelova mitralnog aparata.

\section{I.I. Indikacije za kirurški zahvat}

Odluka o tome hoće li se učiniti zamjena zaliska ili nijhov popravak ovisi o anatomiji valvule, kirurškoj ekspertizi i stanju bolesnika.

Kirurški zahvat je indiciran kod MR koji imaju simptome uzrokovane kroničnom MR i koji nemaju kontraindikacije za kirurški zahvat. Kada je LVEF < $30 \%$ kirurški popravak kao trajno rješenje može smanjiti simptome, iako nije potpuno poznat njen učinak na preživljavanje.

Perkutane edge-to edge intervencije treba uzeti u obzir kod bolesnika s teškom primarnom MR koij imaju simptome, koji zadovoljavaju ehokardiografske kriterije porodnosti i koil su procijenieni kao inoperabini il kod kojh "stručn tim za sice." ( grodine.

Liječenje bolesnika koji nemaju simptome je proturječno. Indikacije za kirurški zahvat ovise $\circ$ procjeni rizika, mogućnostima trajnog popravka zaliska i volji informiranog bolesnika.

\section{I.2. Liječenje lijekovima}

Primjena vazodilatatora, uključujući i ACE-inhibitore ne preporučuje se kod kronične MR kod koje nema srčanog popuštanja (HF)

\section{I.3. Kontrole}

Bolesnici bez simptoma $s$ teškom MR i očuvanom funkcijom LV trebaju se kontrolirati svakih 6 mjeseci, a ehokardiografiju treba učiniti jednom godišnje: kontrole treba skratiti ako nemamo prethodnu procjenu, kao i kod bolesnika $s$ graničnim vrijednostima te kod kojih je došlo do većih promjena od zadnje kontrole. 

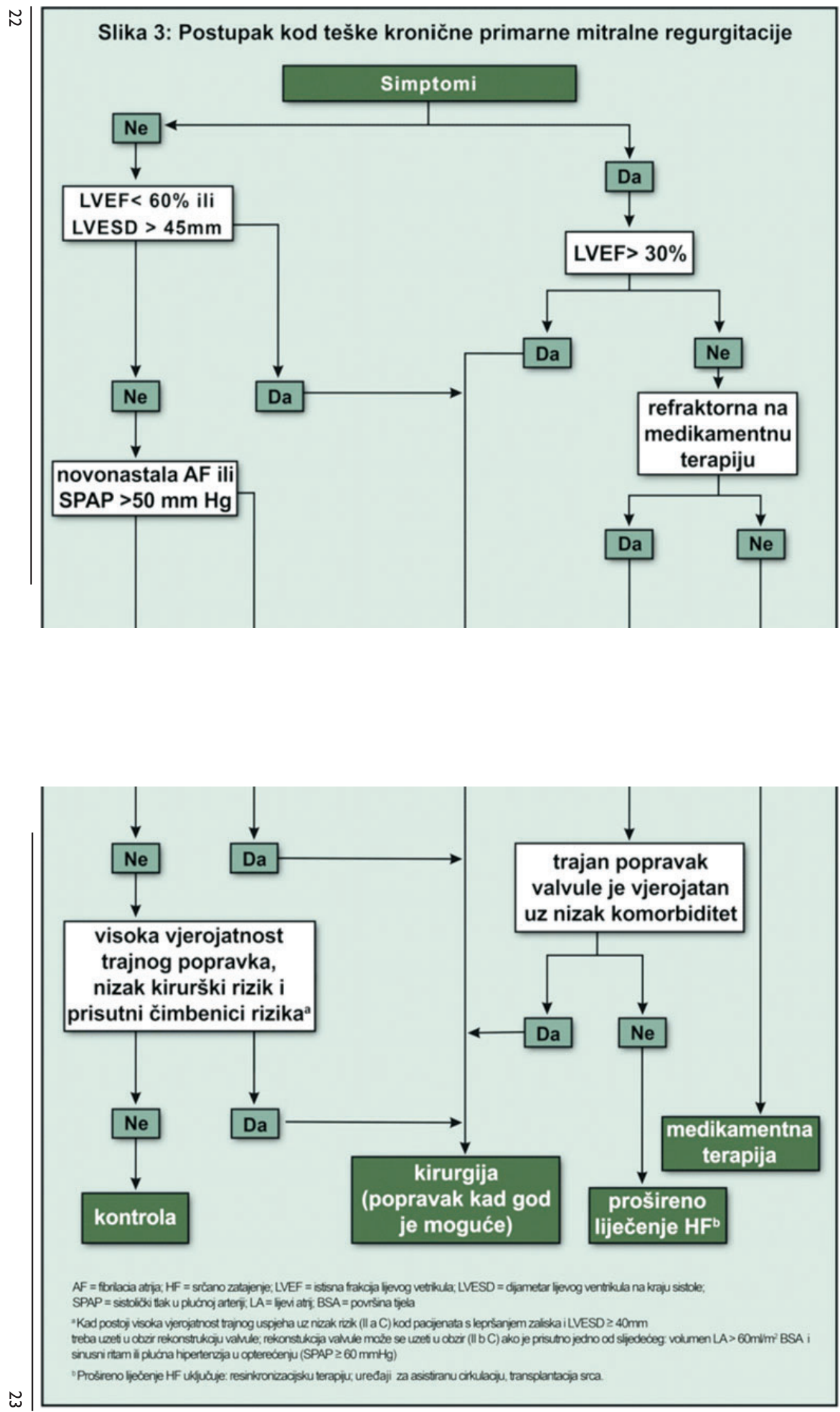
Tablica I I. Indikacije za kirurški zahvat kod teške

primarne mitralne regurgitacije

\begin{tabular}{|c|c|c|}
\hline & Razred $^{a}$ & Razina $^{b}$ \\
\hline $\begin{array}{l}\text { Popravak mitralnog zaliska ima prednost kada je trajno } \\
\text { rješenje. }\end{array}$ & I & C \\
\hline $\begin{array}{l}\text { Kirurški zahvat je indiciran kod bolesnika sa simptomima } \\
\text { koji imaju LVEF }>30 \% \text { i LVESD }<55 \mathrm{~mm} \text {. }\end{array}$ & I & B \\
\hline $\begin{array}{l}\text { Kirurški zahvat je indiciran kod bolesnika bez simptoma } \\
\text { s disfunkcijom LV (LVESD } \geq 45 \mathrm{~mm} \text { i/ili LVEF } \leq 60 \%)\end{array}$ & I & C \\
\hline $\begin{array}{l}\text { Kirurški zahvat treba uzeti u obzir kod bolesnika bez } \\
\text { simptoma s očuvanom funkcijom LV i novonastalom } \\
\text { fibrilacijom atrija i plućnom hipertenzijom (sistolički } \\
\text { plućni tlak u mirovanju }>50 \mathrm{mmHg} \text { ). }\end{array}$ & Ila & C \\
\hline $\begin{array}{l}\text { Kirurški zahvat treba uzeti u obzir kod bolesnika } \\
\text { bez simptoma s očuvanom funkcijom LV, visokom } \\
\text { vjerojatnośću trajnog popravka, niskim operacijskim } \\
\text { rizikom, lepršanjem (engl.flail)listića i LVESD } \geq 40 \mathrm{~mm} \text {. }\end{array}$ & Ila & B \\
\hline $\begin{array}{l}\text { Kirurški zahvat treba uzeti u obzir kod bolesnika } \\
\text { teškom disfunkcijom LV (LVEF } \leq 30 \% \text { i/ili LVESD }>55 \mathrm{~mm} \text { ) } \\
\text { kod kojih liječenje lijekovima nije učinkovito a postoji } \\
\text { visoka vjerojatnost trajnog popravka i nema pridruženih } \\
\text { bolesti. }\end{array}$ & Ila & C \\
\hline $\begin{array}{l}\text { Kirurški zahvat treba uzeti u obzir kod bolesnika } \\
\text { teškom disfunkcijom LV (LVEF } \leq 30 \% \text { i/ili LVESD }>55 \mathrm{~mm} \text { ) } \\
\text { kod kojih liječenje lijekovima nije učinkovito a postoji } \\
\text { manja vjerojatnost trajnog popravka i nema pridruženih } \\
\text { bolesti. }\end{array}$ & Ilb & C \\
\hline $\begin{array}{l}\text { Kirurški zahvat treba uzeti u obzir kod bolesnika } \\
\text { bez simptoma očuvanom funkcijom LV s visokom } \\
\text { vjerojatnošću trajnosti popravka, niskim kirurškim } \\
\text { rizikom i: } \\
\text { • uvećanjem lijeve pretklijetke (volumni indeks } \\
\text { • } 260 \mathrm{ml} / \mathrm{m}^{2} \mathrm{BSI} \text { ) sa sinusnim ritmom ili } \\
\text { plućnom hipertenzijom u opterećenju (SPAP } \\
\geq 60 \mathrm{mmHg} \text { opterećenju) }\end{array}$ & Ilb & C \\
\hline
\end{tabular}

BSA = povrsina tijela; $L V=$ lijeva klijetka; $L$ VEF $=$ istisna frakcta
klijetke na kraju dijastole; SPAP = sistolički plućni arterijski tlak.

aRazred preporuke; bRazina dokaza

\subsection{Sekundarna MR}

ekundarna MR još se naziva i ,funkcionalna MR" i ima normalnu strukturu srčanih listića i kordi, a MR je posljedica geometrijskog izobličenja subvalvularnog aparata, koje je uzrokovano uvecanjem LV injovim preoblikovanjem (remodeliranjem) zbog idiopatske kardiomiopatije ili CAD

\subsection{Indikacije za intervenciju}

Različiti podaci kod sekundarne MR imaju za posljedicu liječenje koje je manje zasnovano na dokazima, za razliku kod primarne MR. Teska se MR treba korigirati istovremeno kada se izvodi aortokoronarno premoštenje. Kod drugih bolesnika indikacija za kirurški zahvat se bazira na procjeni kirurškog rizika, mogucnosti revaskularizacije, funkcije LV, vijabilitetu miokarda, a kod probranih bolesnika promjenama u testu opterecenja. Perkutane edge-to-edge tehnike mogu se uzeti u obzir kod bolesnika s teškom MR koji imaju simptome unatoč najjacem liječenju s lijekovima, te koji ispunjavaju ehokar diografske kriterje pogocnosti, kojl su procijenjeni kao inoperabihi ili visoko rizični za kirurški zahvat od strane kardiologa i trajanje životnog vijeka dulje od jedne godine.

\subsubsection{Liječenje lijekovima}

Sveobuhvatna terapija koja uključuje lijekove, resinkronizacijsku terapiju i postavljanje

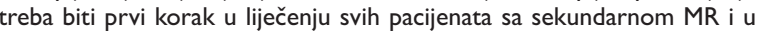
skladu sa smjernicama za srčano popuštanje (HF).

Tablica 12. Indikacije za kirurški zahvat na mitralnom zalisku kod kronične sekundarne mitralne regurgitacije

Razred $^{\mathrm{a}}$ Razina $^{\mathrm{b}}$

Indiciran je kod bolesnika s teškom MRc koji se podvrgava CABG s LVEF $>30 \%$.

Treba uzeti u obzir kod bolesnika s umjerenom MR koji se

Treba uzeti u obzir kod bolesnika sa simptomima i teškom MR, LVEF $<30 \%$, mogućnošću revaskularizacije i dokazanim vijabilitetom.

Može se uzeti u obzir kod bolesnika s teškom MR s LVEF $>30 \%$ koji imaju simptome unatoč optimalnoj medikamentno terapiji (ukljucujuci i CRT ako je indicirana) te koji imaju nizak komorbiditet a revaskularizacija nije indicirana.

\begin{tabular}{l|l|l}
\hline & $c$
\end{tabular}

jska terapiin: klijetke; $\mathrm{MR}=$ mitralna regurgitacija; SPAP = sistoličcki tlak u plućnoj arteriii 


\section{MITRALNA STENOZA}

\section{I. Indikacije za zahvat}

Zahvat bi se trebao učiniti samo kod bolesnika s klinički značajnom MS koji imaju površinu zaliska $\leq 1,5 \mathrm{~cm} 2$. Odluka o načinu i vremenu liječenja zasniva se na kliničkim podacima koji uključuju funkcionalni status i operacijski rizik PMC, te anatomiji i ekspertizi stručnog tima.

Zahvat se radi u bolesnika koji imaju simptome. Većina bolesnika koji imaju pogodnu anatomiju danas se podvrgava PMC. Kod donošenja odluke o zahvatu kod bolesnika s nepovoljnim anatomskim karakteristikama treba uzeti u obzir da više čimbenika utječe na predikciju rezultata PMC.

Bolesnici koji nemaju nikakvih simptoma obično nisu kandidati za zahvat zbog malog. ali postojećeg rizika koji nosi PMC, osim kada postoji povećan tromboembolijski rizik ili narušavanje hemodinamske ravnoteže.

\subsection{Medikamentna terapija}

Diuretici, betablokatori i antagonisti kalcijevih kanala mogu povisiti toleranciju na napor. Kod bolesnika koji su u sinusnom ritmu lijekovi protiv zgrušavanja krvi su indicirani samo kod preboljele embolije ili postojećeg tromba u lijevoj pretklijetki. Kada se transezofagealnim ultrazvukom srca (TEE) nađe gusti spontani kontrast ili uvećanje lijeve pretklijetke (M-načinom utvrđen dijametar $>50 \mathrm{~mm}$ ili LA volumen $>60$ $\mathrm{ml} / \mathrm{m} 2$ ) treba razmotriti uvođenje lijekova protiv zgrušavania.

\subsection{Kontrole}

Bolesnici bez simptoma s klinički značajnom MS, koji se ne podvrgavaju intervenciji, trebaju se kontrolirati svake godine klinički i ultrazvučno. Liječenje bolesnika nakon uspješne PMC slično je liječenju bolesnika bez simptoma. Kada je PMC neuspješna a simptomi i dalje postoje treba se razmotriti mogućnost kirurškog zahvata, ukoliko za nj ne postoje kontraindikacije.

Tablica 13. Kontraindikacije za perkutanu mitralnu komisurotomiju

- Površina mitralne valvule $>1,5 \mathrm{~cm} 2$

- Tromb u lijevom atriju

- Umjerena ili teška mitralna regurgitacija

- Teška kalcifikacija obiju komisura

- Nedostatak komisuralnog spajanja

- Teška istovremenabolest aortnog zaliska ili teška kombinirana trikuspidalna stenoza i regurgitacija.

- Istovremena koronarna bolest koja zahtijeva aortokoronarno premoštenje

\begin{tabular}{|c|c|c|}
\hline & Razred $^{a}$ & Razina $^{b}$ \\
\hline $\begin{array}{l}\text { Indicirana je kod bolesnika sa simptomima is pogodnim } \\
\text { osobinama.c }\end{array}$ & I & C \\
\hline $\begin{array}{l}\text { Indicirana je kod bolesnika sa simptomima kod kojih } \\
\text { postoji kontraindikacija ili visoki rizik za kirurški zahvat. }\end{array}$ & Ila & c \\
\hline $\begin{array}{l}\text { Treba uzeti u obzir kao početni tretman kod bolesnika sa } \\
\text { simptomima s nepovoljnim anatomskim karakteristikama, } \\
\text { ali bez nepovoljnih kliničkih karakteristika.c }\end{array}$ & Ila & C \\
\hline $\begin{array}{l}\text { Treba uzeti u obzir kod bolesnika bez simptoma i bez } \\
\text { nepovoljnih karakteristikaci: } \\
\text { visokim tromboembolijskim rizikom } \\
\text { (preboljelom embolijom, gustim spontanim } \\
\text { kontrastom u lijevoj pretklijetki, nedavnim } \\
\text { napadajem fibrilacije atrija) i/ili } \\
\text { visokim rizikom razvoja hemodinamske } \\
\text { nestabilnosti (sistolički plućni tlak >50 mmHg u } \\
\text { mirovanju, potreba veciih nekardijalnih operacija, } \\
\text { želja za trudnoćom). }\end{array}$ & Illb & C \\
\hline
\end{tabular}

NYHA = New York Heart Association; PMC = perkutana mitralna komisurotomija.

'Razred preporuke; 'Razina dokaza

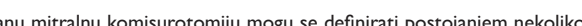
navedenih karakteristika: 

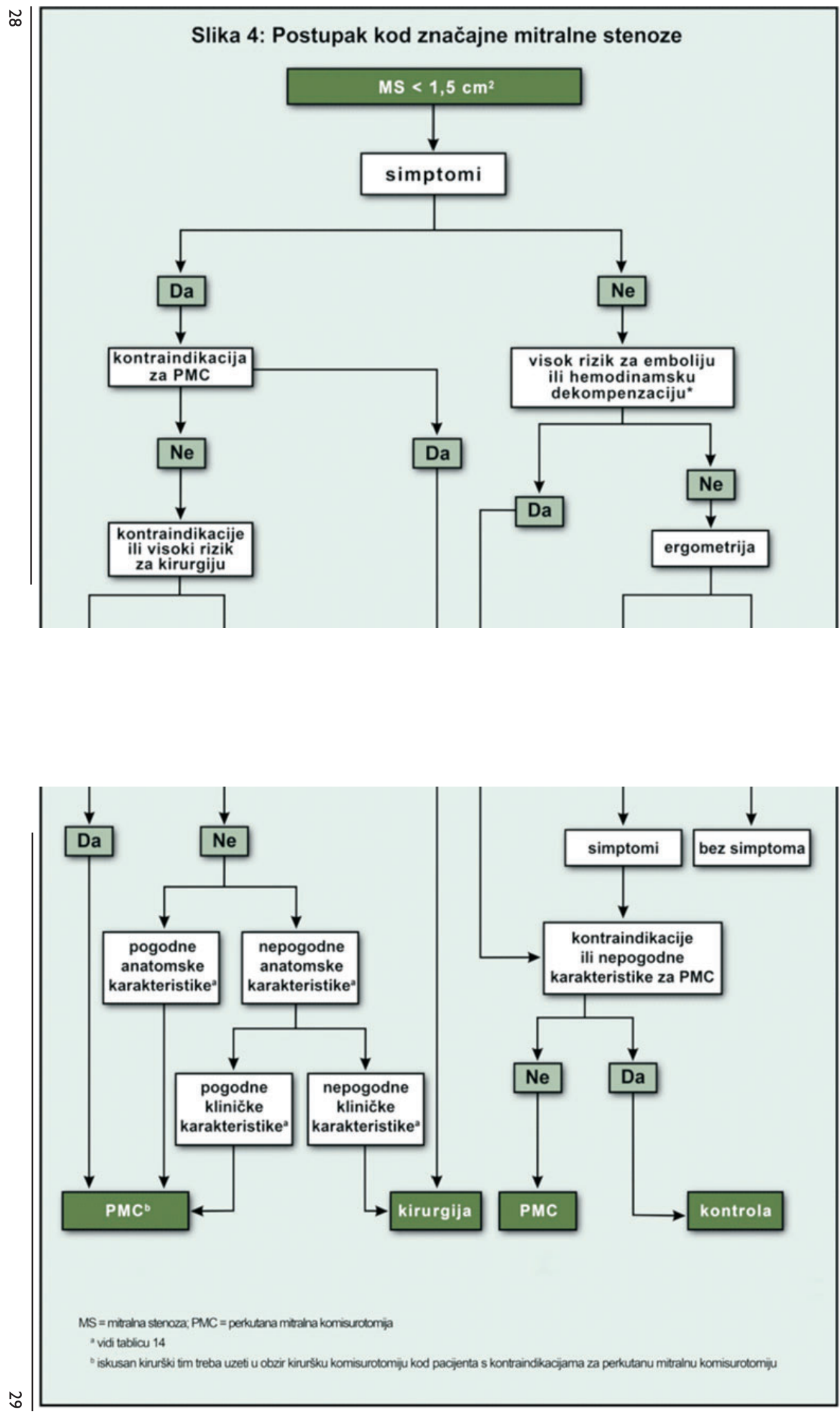
Kliničke karakteristike: poodmakla dob, prethodna komisurotomija, NYHA razred IV, permanentna fibrilaciia atrija, teška plućna hipertenzija.

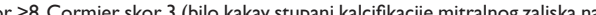
osnovi fluoroskopske prociene), veoma mala mitralna valvula, teška trikuspidalna regurgitacija.

\section{BOLEST TRIKUSPIDALNOG ZALISKA}

Potrebna je pažljiva prociena kada se otkrije, s obzirom na to da je gotovo uvijek pridružena bolestima zalistaka lijevog srca koje dominiraju kliničkom slikom.

\section{I. Indikacije za kirurgiju}

Kirurški se zahvat mora učiniti pravovremeno kako ne bi došlo do ireverzibilnih promjena desne klijetke.

Ako je to moguće izvesti, kirurški zahvat s popravkom ima prednost pred zamjenom zaliska, kada svakako treba dati prednost biološkom zalisku.

Kod bolesnika sa izoliranom stenozom trikuspidalnog zaliska ili kod kojih se provodi PMC na mitralnom zalisku najprije treba pokušati s perkutanom balonskom valvuloplastikom.

\begin{tabular}{|l|c|c|}
\hline \multicolumn{3}{|c|}{ Tablica I5. Indikacije za kirurški zahvat na trikuspidalnom zalisku } \\
\hline & Razred $^{\text {a }}$ & Razina $^{\text {b }}$ \\
\hline Indiciran je kod bolesnika sa simptomima kod teške TS. & I & C \\
\hline $\begin{array}{l}\text { Indiciran je kod bolesnika s teškom TS koji se podvrgavaju } \\
\text { lijevostranim valvularnim zahvatima. }\end{array}$ & I & C \\
\hline $\begin{array}{l}\text { Indiciran je kod bolesnika s teškom primarnom ili } \\
\text { sekundarnom TR koji se podvrgavaju lijevostranim } \\
\text { valvularnim kirurškim zahvatima. }\end{array}$ & I & C \\
\hline $\begin{array}{l}\text { Indiciran je kod bolesnika sa simptomima s teškom } \\
\text { izoliranom primarnom TR bez teške disfunkcije desne } \\
\text { klijetke. }\end{array}$ & I & C \\
\hline $\begin{array}{l}\text { Treba ga uzeti u obzir kod bolesnika s umjerenom } \\
\text { primarnom TR koji se podvrgavaju kirurgiji lijevostranih } \\
\text { zalistaka. }\end{array}$ & Ila & $\mathrm{C}$ \\
\hline $\begin{array}{l}\text { Treba ga uzeti u obzir kod bolesnika s blagom ili umjerenom } \\
\text { sekundarnom TR s proširenim prstenom }(\geq 40 \text { mm ili }>21 \\
\left.\text { mm } / \mathrm{m}^{2}\right) \text { koji se podvrgavaju kirurgiji lijevostranih zalistaka. }\end{array}$ & Ila & $\mathrm{C}$ \\
\hline
\end{tabular}

Treba ga uzeti u obzirkod bolesnika bez simptoma ili s blagim simptomima $s$ teskom izoliranom primarnom $T R$ progresivnom dilatacijom desne klijetke ili pogoršanjem

Treba ga uzeti u obzir kod bolesnika $s$ teškom TR sa

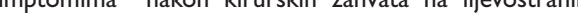
zaliscima ill koji imaju sve vece šrenje/disfunkciju desne deste, odsutnosti disfunkcije lijevostranih valvula, teske plućne vaskularne bolesti.

$P M C=$ perkutana mitralna komisurotomija; $T R=$ trikuspidalna regurgitaciia: $T S=$ trikuspidalna stenoza

\section{UMJETNI ZALISCI}

Dobar izbor umjetnog zaliska kao i njegovo daljnje praćenje ključno je da se izbjegnu komplikacije s njim povezane.

\section{I. Izbor umjetnih zalistaka}

Izbor umjetnog zaliska mora se zasnivati na uzimanju u obzir više čimbenika među kojima su profil bolesnika, poštivanje volje dobro informiranog bolesnika i lokalnih mogućnosti.

Oba tipa proteza prihvatljiva su kod bolesnika između 60 i 65 godina koji trebaju aortnu protezu i 65 do 70 godina koji trebaju mitralnu protezu, pa se u njihovu izboru treba voditi drugim čimbenicima, pored dobi. 


\begin{tabular}{|l|c|c|}
\hline \multicolumn{1}{|c|}{$\begin{array}{l}\text { Tablica I6. Izbor aortne/mitralne proteze: u prilog mehaničkoj protezi } \\
\text { Odluka se zasniva na integraciji nekoliko od sljedećih čimbenika }\end{array}$} \\
\hline $\begin{array}{l}\text { Preporučuje se ako je to volja informiranog } \\
\text { bolesnika i ako ne postoje kontraindikacije za trajnu } \\
\text { antikoagulacijsku terapiju. }\end{array}$ & I & C \\
\hline $\begin{array}{l}\text { Preporučuje se kod bolesnika s rizikom ubrzanog } \\
\text { strukturnog propadanja zaliska. }\end{array}$ & Razina \\
\hline $\begin{array}{l}\text { Preporučuje se kod bolesnika koji su već na } \\
\text { antikoagulacijskoj terapiji zbog mehaničke proteze na } \\
\text { drugom zalisku. }\end{array}$ & I & C \\
\hline $\begin{array}{l}\text { Treba je uzeti u obzir kod bolesnika koji su mlađi od } \\
60 \text { godina kod aortne proteze i mlađi od } 65 \text { godina } \\
\text { kod mitralne proteze. }\end{array}$ & Ila & C \\
\hline $\begin{array}{l}\text { Treba je uzeti u obzir kod bolesnika s razumnim } \\
\text { očekivanim trajanjem životnog vijeka kod kojih bi } \\
\text { budući kirurški zahvat bio visokorizičan. }\end{array}$ & Ila & C \\
\hline $\begin{array}{l}\text { Može ga se uzeti u obzir kod bolesnikana već } \\
\text { dugotrajnoj antikoagulacijskoj terapiji zbog visokog } \\
\text { tromboembolijskog rizika. }\end{array}$ & Ilb & C \\
\hline
\end{tabular}
tromboembolijskog rizika.

aRazred preporuke; bRazina dokaza

'Povećan rizik krvarenja zbog komorbiditeta, opreza zbog neuzimanja terapije, geografski, stil Thota i posebnosti profesije.

eKod bobsik godina koii trebaju mitralnu pros pažljivu analizu i drugih čimbenika. 'Očekivano trajanje života se procijn i specifično očekivano trajanje života za dotičnu zemlju.

8Rizični čimbenici za tromboemboliju su fibrilacija atrija, preboljela tromboembolija, stanje hiperkoagulabilnosti, teška sistolička disfunkcija lijevog ventrikula.

Tablica 17. Izbor aortne/mitralne proteze: u prilog biološke proteze Odluka se zasniva na integraciji nekoliko od sljedećih čimbenika

Razred $^{\mathrm{a}}$ Razina $^{\mathrm{b}}$

Preporučuje se ako je to volja informiranog bolesnika. Preporučuje se kada postoji problem kvalitetne antikoagulacijske terapije (neuzimanje lijeka, nepravilna dostupnost) ili je kontraindicirana zbog visokog rizika krvarenja (ranija velika krvarenja; komorbiditeti; otpor uzimanju lijekova i problemi s redovitim uzimanjem lijekova; životni stil, profesija) Preporučuje se kod reoperacija mehaničkog zaliska zbog tromboze, unatoč dobroj dugotrajnoj antikoagulacijskoj kontroli.

Treba uzeti u obzir kod bolesnika kod kojih bi buduće kirurške reoperacije bile niskog rizika.

Treba uzeti u obzir kod mladih žena koje razmišljaju o trudnoći.

Treba uzeti u obzir kod bolesnika starijih od 65 godina za aortne proteze ili starijih od 70 godina za mitralne proteze ili onih s očekivanim trajanjem životac nižim nego što je očekivano trajanje biološke proteze.d

\section{aRazred preporuke; bRazina dokaza} očekivano trajanje života za dotičnu zemlju. 70 o dobi pažljivu analizu i drugih čimbenik

\subsection{Postupak nakon zamjene zaliska}

\section{2. . Početna procjena i način praćenja}

Početnu procjenu kliničkog stanja te Rtg srca i pluća, EKG, ehokardiografiju i laboratorijske nalaze najbolje je učiniti 6 do 12 tjedana nakon kirurškog zahvata, ako nije učinjena na kraju hospitalizacije. 
Kliničku procjenu treba učiniti jednom godišnje, a što prije ako se pojave neki novi srčani simptomi. TTE treba učiniti nakon zamjene valvule ako se pojavi kakav novi simptom ili sumnja na kakvu komplikaciju. Kod bolesnika s biološkim zaliskom, nakon pete godine od operacije preporučuju se godišnje ehokardiografske kontrole. Mjerenja gradijenta kroz protezu treba uspoređivati s početnim vrijednostima kao is teoretskim vrijednostima za dotičnu protezu.

Potrebu transezofagealnog UZV srca (TEE) treba razmotriti u slučaju loše kvalitete transtorakalnog UZV srca (TTE) te u svim slučajevima kada se sumnja ma ošté́enje proteze ili endokarditis. Fluoroskopija i MSCT može biti korisna kod sumnje na tromb ili panus (prerastanje vezivnog tkiva preko prstena umjetnog zaliska).

\subsubsection{Antitrombocitna terapija}

Nakon ugradnje aortne biološke proteze potrebno je uključiti antikoagulacijsku terapiju tijekom 3 mjeseca s niskim dozama aspirina koji se sada preferira kao alternativa.

Usprkos nedostatku dokaza dvoina terapija s kombinacijom niskih doza aspirina i tienopiridinskih preparata koristi se u ranoj fazi nakon TAVI i perkutanih edge-to-edge zahvata, a nakon toga nastavlja se samo $s$ jednim od lijekova. Kombinacija antagonista vitamina $\mathrm{K}$ i aspirina normalno se koristi kod bolesnika s fibrilacijom atrija, ali je treba izvagati zbog povećanog rizika krvarenja.

\begin{tabular}{|c|c|c|}
\hline & Razred $^{a}$ & Razina $^{b}$ \\
\hline $\begin{array}{l}\text { Peroralna antiokoagulacijska terapija se preporučuje } \\
\text { cijeli život kod bolesnika s mehaničkom protezom. }\end{array}$ & I & B \\
\hline $\begin{array}{l}\text { Peroralna antiokoagulacijska terapija se preporučuje } \\
\text { cijeli život kod bolesnika s biološkom protezom i s } \\
\text { drugim indikacijama za antikoagulacijsku terapiju. }\end{array}$ & I & C \\
\hline $\begin{array}{l}\text { Dodatna terapija s niskim dozama aspirina treba se } \\
\text { uzeti u obzir kod bolesnika s mehaničkom protezom i } \\
\text { supostojećom aterosklerotskom bolesti. }\end{array}$ & Ila & C \\
\hline $\begin{array}{l}\text { Dodatna terapija s niskim dozama aspirina treba se } \\
\text { uzeti u obzir kod bolesnika s mehaničkom protezom } \\
\text { nakon tromboembolija unatoč adekvatnom INR. }\end{array}$ & Ila & C \\
\hline
\end{tabular}

\begin{tabular}{|l|c|c|}
\hline $\begin{array}{l}\text { Peroralna antiokoagulacijska terapija treba se uzeti } \\
\text { u obzir tijekom prva } 3 \text { mjeseca nakon implantacije } \\
\text { mitralnog i trikuspidalnog biološkog zaliska. }\end{array}$ & Ila & C \\
\hline $\begin{array}{l}\text { Peroralna antiokoagulacijska terapija treba se uzeti } \\
\text { u obzir tijekom prva } 3 \text { mjeseca nakon popravka } \\
\text { mitralnog zaliska. }\end{array}$ & Ila & C \\
\hline $\begin{array}{l}\text { Niske doze aspirina trebaju se uzeti u obzir prva } 3 \\
\text { mjeseca nakon implantacije aortnog biološkog zaliska. }\end{array}$ & Ila & C \\
\hline $\begin{array}{l}\text { Peroralna antiokoagulacijska terapija može se uzeti } \\
\text { u obzir tijekom prva } 3 \text { mjeseca nakon implantacije } \\
\text { aortnog biološkog zaliska. }\end{array}$ & Illb & C \\
\hline
\end{tabular}
aortnog biološkog zaliska.

\section{INR = međunarodni normalizirani omjer}

hiperkoagulabilno stanje ili s manijm stupnjem dokaza, teška disfunkcija lijevog ventrikula $(\mathrm{EF}<35 \%)$

\section{Ciljni INR}

Kod izbora optimalne vrijednosti INR treba uzeti u obzir rizične čimbenike za svakog pojedinog bolesnika i trombogenost proteze.

\begin{tabular}{|l|c|c|}
\hline \multicolumn{3}{|c|}{ Tablica 19. Ciljni INR kod mehaničkih proteza } \\
\hline \multirow{2}{*}{ Trombogenost proteza } & Rizični čimbenici povezani s bolesnikom ${ }^{\mathrm{b}}$ \\
\cline { 2 - 3 } & & \\
\hline Niska & 2,5 & 3,0 \\
\hline Umjerena & 3,0 & 3,5 \\
\hline Visoka & 3,5 & 4,0 \\
\hline
\end{tabular}

${ }^{a}$ Trombogenost proteza:

Niska = Carbomedics, Medtronic Hall, St.Jude Medical, ON-X:
Nistogenost proteza:

Uiska $=$ Carbomedics, Medtron
Umjerena $=$ drugi dvolisni zalisci,

Visoka = Lillehei-Kaster, Omniscience, Starr-Edwards, Bjork-Shiley i druge valvule s nagibnim diskom.

${ }^{b}$ Rizični čimbenici povezani s bolesnikom: zamjena mitralnog i trikuspidalnog zaliska, ranije tromboembolije, fibrilacija atriia, mitralna stenoza bilo kojeg stupnia, istisna frakcija $<35 \%$ 

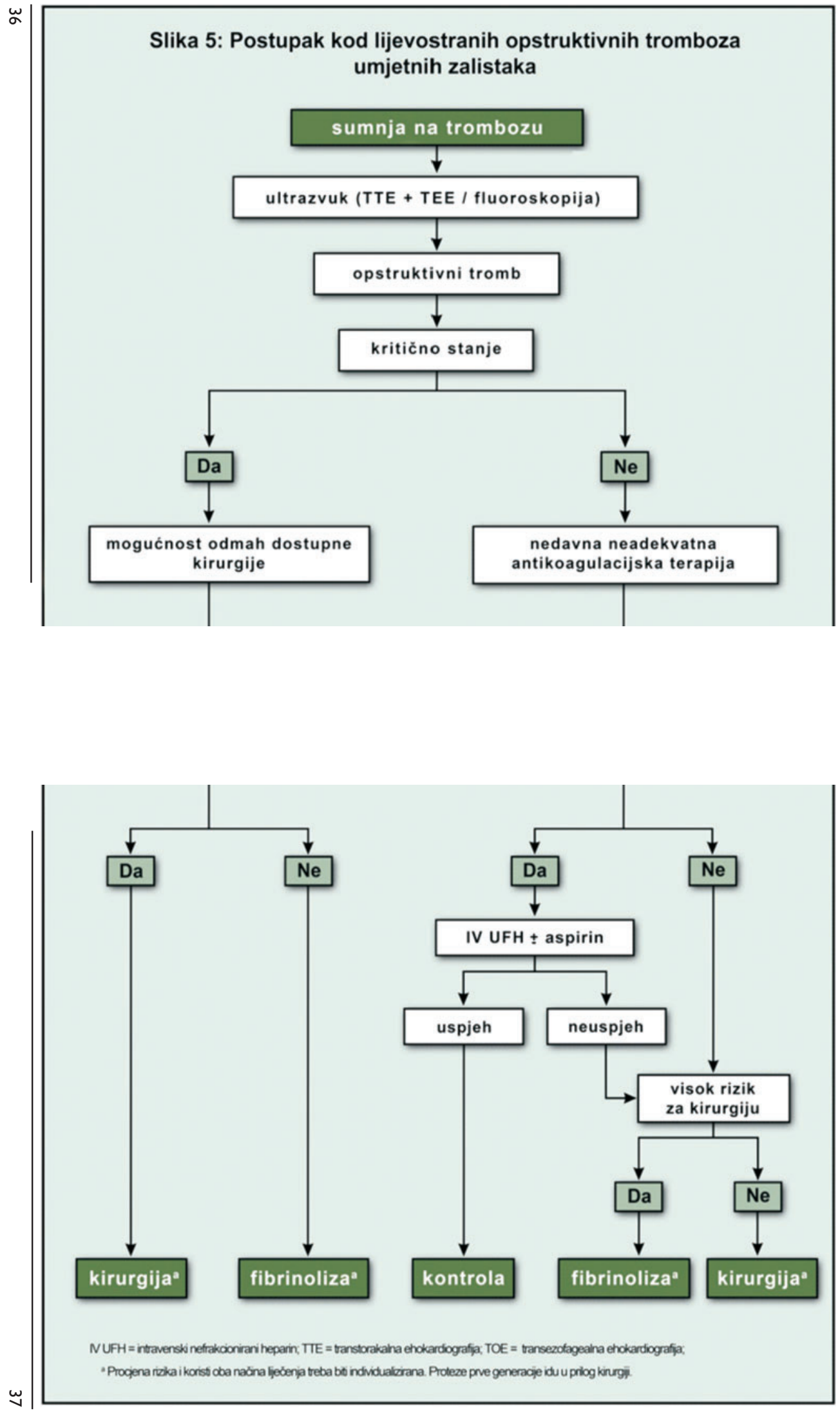


\section{Liječenje predoziranja antagonistima vitamina $\mathrm{K}$ i krvarenja}

Rizik krvarenja znatno raste kada je INR viši od 4,5 a eksponencijalni porast rizika nastaje kod INR $\geq 6,0$. Antikoagulacijsku terapiju tada treba odmah prekinuti zbog rizika krvarenja.

Ako nema krvarenja liječenje ovisi o ciljnom INR, aktualnom INR i poluživotu antagonista vitamina $\mathrm{K}$ koji se koristi.

Vrijeme ponovnog uključenja antikoagulacijske terapije treba odrediti s obzirom na mjesto $i$ tijek krvarenja te učinjene zahvate, $s$ ciljem da se zaustavi krvarenje i/lil liječi uzrok krvarenja.

\section{Kombinacija peroralne antikoagulacijske i antiagregacijske terapije}

Indikacije za dodatnu antitrombocitnu terapiju pored antikoagulacijske terapije uključuju istovremenu bolest atriia posebno bolest koronarnih arterija i druge značajne bolesti ateroskleroze Neobložni stentovi (engl bare metal stents) su bolij izbor od stentova s otpuštanjem lijeka (engl. drug-eluting stents) kod bolesnika s mehaničkim protezama zbog potrebe skraćene jednomjesečne trojne antitrombocitne terapije. Tijekom ovog perioda potrebno je strože praćenje INR vrijednosti i izbjegavanje bilo kakvog predoziranja antikoagulansima. Antitrombocitni lijekovi mogu se dodati i kod ponovne ili jasne embolije s adekvatnim vrijednostima INR nakon detaljne obrade i liječenja identificiranih rizičnih čimbenika i optimizacije antikoagulacijske terapije.

\section{Prekid antikoagulacijske terapije}

Antikoagulaciiska terapija nakon nekardijalnih kirurških zahvata zahtijeva veoma oprezno liječenje koje se bazira na procjeni rizika vezanih za protezu i za pacijenta. Preporučuje se neprekidanje peroralne antikoagulacijske terapije kod većine manjih kirurških zahvata (uključujući vađenje zuba) i onih zahvata kod kojih se krvarenje lako kontrolira. Kod većih kirurških zahvata potrebno je da INR bude $<1,5$. Kod bolesnika $s$ mehaničkim protezama preporučuje se prekid antikoagulacijske terapije i prelaz na heparin.

Nefrakcionirani heparin (UFC) jedini je odobren heparin kod bolesnika s mehaničkim zaliscima Intraventa primje jima prednost pred subkuanom primjenom. Kod pijelaza treba uzeti u obar da je primjea subkuth LMWH zamiena UFH. Kad se koristi LMWH treba ga dati dva puta na dan, koristeći terapeutske doze prilagođene težini tijela i ako je moguće pratiti aktivnost anti-Xa s ciljnom vrijednosti 0,5 do I,0 U/ $\mathrm{ml}$. Učinkovita se antikoagulacija treba uspostaviti što je prije moguće nakon kirurških zahvata, ali uzevši u obzir rizike krvarenja te vrijeme potrebno za postizanje terapijskih vrijednosti INR.

\section{Liječenje tromboze zaliska}

U bolesnika s bilo kojim tipom umjetnog zaliska a koji ima novonastalu zaduhu ili embolijski incident odmah treba posumnjati na opstruktivnu trombozu Analiza rizika i koristi od fibrinolitičke terapije treba se prilagoditi karakteristikama bolesnika i lokalnim mogućnostima.

Hitna ili neočekivana zamjena valvule preporučuje se kod opstruktivne tromboze kod kritičnih bolesnika bez ozbiljnih komorbiditeta.

Fibrinoliza se treba razmotriti u sljedećim situaciiama:

Kritični bolesnik kili ima šnse preživjeti kirurški zahvat.

Situacije kod kojih kirurški zahvat nije odmah dostupan, kod tromboze umjetnog trikuspidalnog zaliska i zaliska plućne arteriie.

Kada se primjenjuje fibrinoliza kod nestabilnih bolesnika preporučuje se kratak protokol intravenskom primjenom aktivatora rekombinantnog tkivnog plazminogena $10 \mathrm{mg}$ u bolusu $+90 \mathrm{mg} \mathrm{kroz} 90$ minuta s UFH ili primjena streptaze I $500000 \mathrm{IU}$ kroz 60 minuta. Kod stabilnih bolesnika mogu se koristiti dugotrajnije infuzije.

Liječenje bolesnika $s$ neopstruktivnim trombozama proteze ovisi o učestalosti i veličini tromboze. Strože praćenje ehokardiografijom i/lil fluoroskopijom je obavezno. Prognoza je povolina s medikamentnom terapijom u vé́ini slučjera s malim trombom (duljine $<10 \mathrm{~mm}$ ). Dobar učinak s postupnim otapanjem tromba uklanja potrebu kirurškog zahvata ili fibrinolize. Naprotiv, kirurški zahvat se preporučuje potrebu kirurškog zahvata ili fibrinolize. Naprotiv, kirurski zahvat se preporučuje
kod većih tromba $(\geq 10 \mathrm{~mm})$ kod neopstruktivne tromboze proteze s embolijskom kod većih tromba $(\geq 10 \mathrm{~mm})$ kod neopstruktivne tromboze proteze s embolisk
komplikacijom i koja se ne smanjuje usprkos dobroj antikoagulacijskoj terapiji. komplikacijom i koja se ne smanjuje usprkos dobroj antikoagulacijskoj terapiji.
Temeljito ispitivanje svake pojave tromboembolije ključan je čimbenik koji nam omogućuje ispravno liječenje. Prevencija budućih tromboembolijskih događaja uključuje liječenje ili uklanjanje čimbenika rizika na koje se može utjecati, poboljšanje antikoagulacijske kontrole i po mogućnosti samokontrolu od strane samih bolesnika. Ukoliko ranije nije propisan, treba dodati Aspirin u niskim dozama ( $\leq 100 \mathrm{mg}$ ).

\subsubsection{Liječenje hemolize i paravalvularnog propuštanja}

Preporučuje se ponovna operacija ako je paravalvularno propuštanje (PVL) povezano s endokarditisom, ako uzrokuje hemolizu koja zahtijeva ponovljene transfuzije krvi ili ako stvara teške simptome. Medikamentna terapija koja uključuje nadoknadu željeza, betablokatore te eritropoetin indicirana je kod bolesnika $s$ teškom hemolitičkom anemijom i paravalvularnim propuštanjem koji nisu vezani za endokarditis te kada postoji kontraindikacija za kirurški zahvat. Zatvaranje PVL pomoću katetera može se uzeti u obzir kod bolesnika s kontraindikacijama za ponovni kirurški zahvat ili ako se smatra da je isti visokorizičan. 

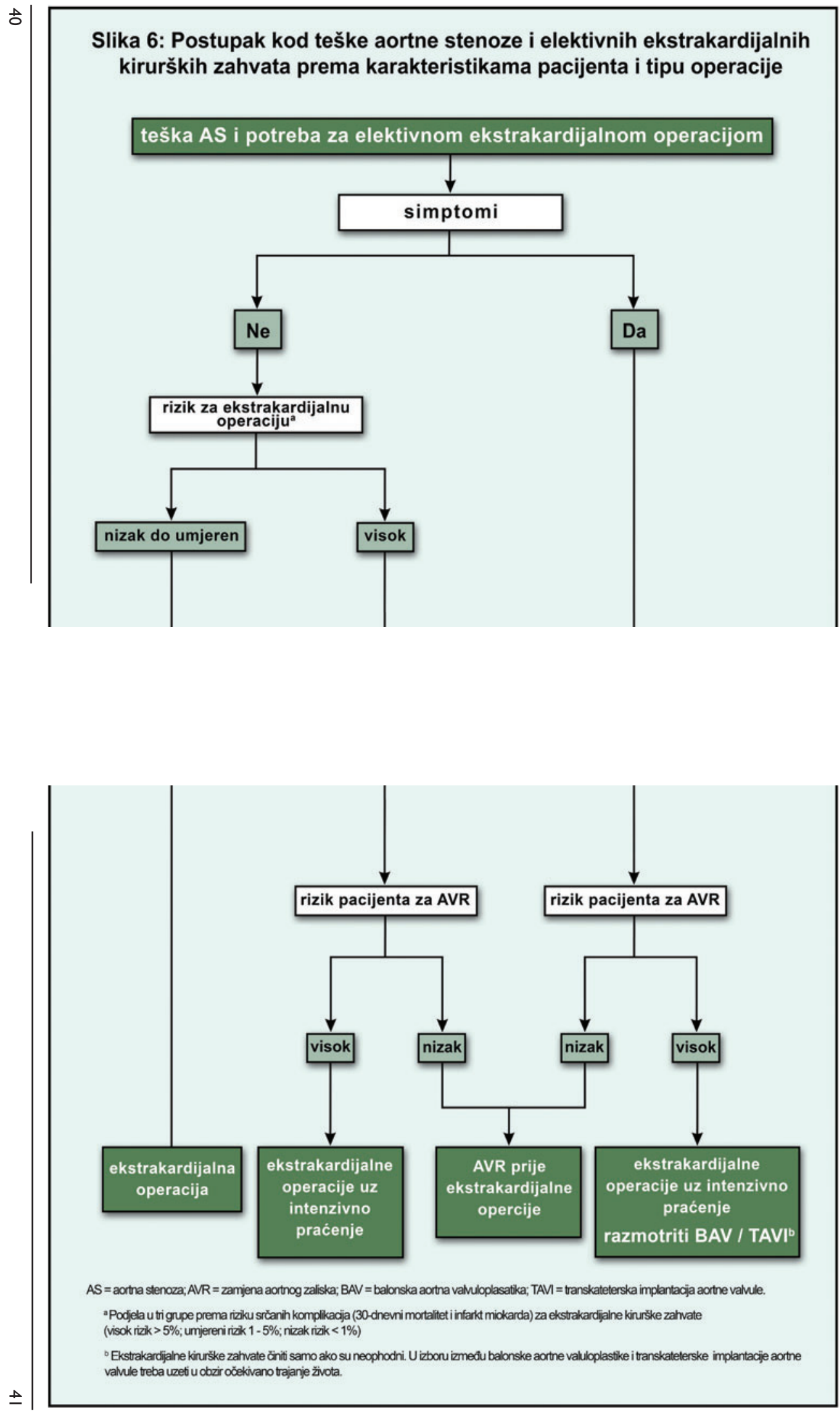


\subsubsection{Liječenje oštećenog biološkog zaliska}

Ponovna operacija se preporučuje kod bolesnika koji imaju simptome sa značajnim porastom gradijenta kroz valvularnu protezu ili tešku regurgitaciju. Kod bolesnika koji su bez simptoma a imaju značajno oštecenje proteze treba uzeti u obzir ponovnu operaciju, uz uvjet da ona ima nizak rizik. Perkutane balonske intervencije treba izbjegavati u liječenju stenoziranih lijevostranih proteza Implantacija zaliska u zalistak pomocu katetera moź

\subsubsection{Srčano zatajenje}

U slučaju zatajenja srca nakon operacije zaliska treba tražiti moguće komplikacije koje su vezane za umjetni zalistak, njegovo propadanje, zatim poremećaj funkcije lijeve klijetke ili progresiju bolesti nekog drugog zaliska. Treba također uzeti u obzir i druge uzroke koji nisu povezani sa zaliscima kao što su koronarna bolest, hipertenzija ili postojana aritmija. Liječenje bolesnika sa srčanim zatajenjem (HF) treba biti u skladu s odgovarajućim smjernicama.

\section{POSTUPAK KOD NEKARDIJALNIH OPERACIJA}

Perioperativni postupak kod bolesti srčanih zalistaka (VHD) detaljno je opisan u posebnim ESC Smjernicama.

Svaki slučaj se razmatra pojedinačno između kardiologa i anesteziologa (idealno kardiološkog anesteziologa) te kirurga (kardiokirurga i onog koji izvodi nekardiološku operaciju) te bolesnika i njegove obitelji.

Hitnu nekardijalnu operaciju kod bolesnika s teškom AS treba izvesti pod strogom hemodinamskom kontrolom. Kod bolesnika $s$ teškom AS koji trebaju elektivnu nekardijalnu operaciju liječenje ovisi uglavnom o prisutnosti simptoma i tipu kirurškog zahvata (Slika 6).

Kod bolesnika bez simptoma sa značajnom MS i sistoličkim tlakom u plućnoj arteriji $<50 \mathrm{mmHg}$ nekardijalni kirurški zahvat se može obaviti uz nizak rizik. Kod bolesnika koji imaju simptome ili kod onih koji imaju sistolički tlak u plućnoj arteriji $>50$ $\mathrm{mmHg}$ rješavanje MS pomoću PMK treba pokušati kad god je to moguće prije same nekardijalne operacije.

Kod bolesnika s teškom MR ili AR i očuvanom funkcijom LV nekardijalni kirurški zahvat može se učiniti uz nizak rizik. Kod bolesnika koji imaju simptome ili onih s oštećenom funkcijom LV (EF <30\%) nekardijalni kirurški zahvat treba učiniti samo ako je neophodno potreban.

\section{I. POSTUPAK ZA VRIJEME TRUDNOĆE}

Liječenje VHD za vrijeme trudnoće opisano je u ESC Smjernicama za trudnoću.

Ukratko, liječenje prije i za vrijeme trudnoće te planiranje poroda zahtijeva konzultaciju opstetričara, kardiologa te bolesnika i njegove obitelji u skladu s odgovarajućim smjernicama. Najbolje je ako se valvularna bolest može procijeniti prije trudnoće i po mogućnosti riješiti. U određenim situacijama trudnoća se ne savjetuje. 
Bilješke

Bilješke

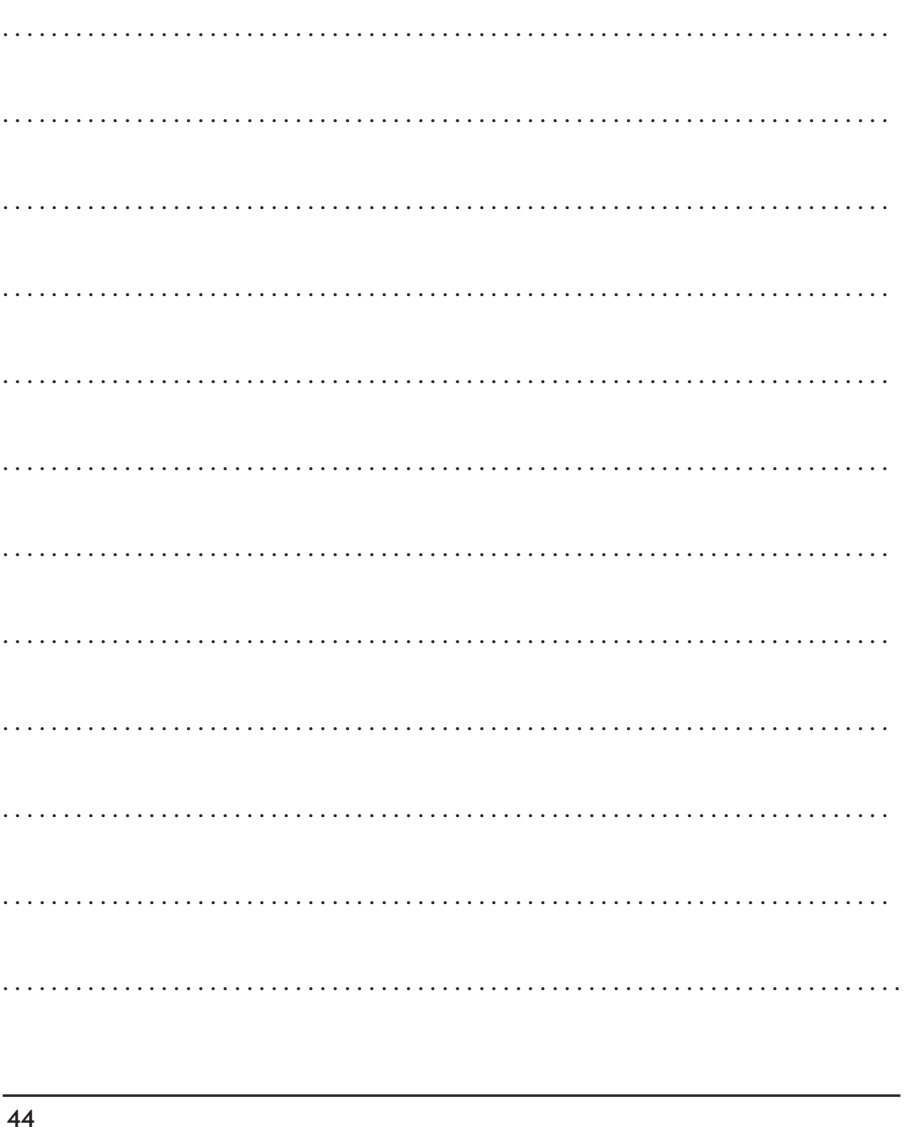

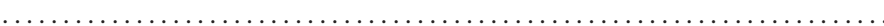

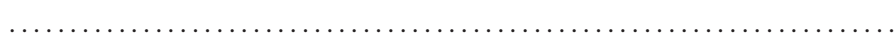

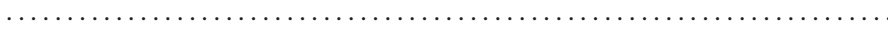

, 
Bilješke

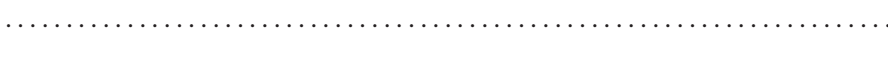

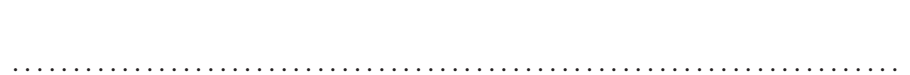

46 (๑) 2012 The European Society of Cardiology
No part of these Pocket Guidelines may be translated or reproduced in any
form without written permission from the ESC

The following material was adapted from the ESC/EACTS Guidelines on the Management Eur 109 . To read the full report as published by the European Society of Cardiology, visit our

Www.escardio.orglguidelines
Copyright $\odot$ European Society of Cardiology 2012 - All Rights Reserved The content of these European Society of Cardiology (ESC) Guidelines has been published for personal and educational use only. No commercial use is authorized
No part of the ESC Guidelines may be translated or reproduced in any form without written permission from the ESC. Permission can be obtained upon submission of written permission from the ESC. Permission can be obtained upon submission of a
written request to ESC, Practice Guidelines Department,2035, route des Colles - Les
Templiers - BPI79 - 06903 Sophia Antipolis Cedex - France.

The ESC and EACTS Guidelines represent the views of the ESC and EACTS which were arrived at after careful consideration of the available evidence at the time they were written. Health professionals are encouraged to take them fully into account when exercising their clinical judgement. The guidelines do not, however, override the circumstances of the individual patients, in consultation with that patient and where appropriate and necessary the patient's guardian or carer. It is also the health professional's responsibility to verify the rules and regulations applicable to drugs and devices at the time of prescription.

Niti jedan dio ovi $\bigcirc 2012$ Europsko kardiološko društvo

Smjernica ne smije biti preveden ili reproduciran u bilo

Copyright $\odot$ European Society of Cardiology 2007 - Sva prava pridržana Sadrzaj ovih smiernica Europskog Kardiološkog Društva (ESC) objavljen je isključivo za osobnu i edukacijsku upotrebu. Upotreba u komercijalne svrhe nije dopuštena. Nit jedan dio ovih ESC Smjernica ne smije biti preveden ili reproduciran u bilo kojem obliku bez pisanog dopustenja ESC

Eno pismenim zahtievom ESC, Practice Guidelines Depres

Smjertichice Europskog Kardiološkog Društva predstavljaju stavove ESC i donešene su nakon detaljnog izucavanja dokaza dostupnih u vrijeme kada su pisane. Zdravstven prosudbi. Smjernice, medutim, ne oslobadaju zdravstrvene djelatnike od osobne odgovornosti pri donošenju primjerene odluke prilagođene okolnostima kod pojedinog pacijenta, u dogovoru s pacijentom te, gdje postoji potreba, u dogovoru da potvrdi pravila i odredbe koje vrijede za lijekove i naprave u vrijeme kada se one propisuju. 




